\title{
Survival benefit of glioblastoma patients after FDA approval of temozolomide concomitant with radiation and bevacizumab: $\mathbf{A}$ population-based study
}

\author{
Ping Zhu ${ }^{1,2}$, Xianglin L. Du ${ }^{1}$, Guangrong Lu ${ }^{2}$ and Jay-Jiguang Zhu ${ }^{2}$ \\ ${ }^{1}$ Department of Epidemiology, Human Genetics, and Environmental Sciences, The University of Texas Health Science Center \\ at Houston (UTHealth), School of Public Health, Houston, TX 77030, USA \\ ${ }^{2}$ The Vivian L. Smith Department of Neurosurgery, The University of Texas Health Science Center at Houston (UTHealth), \\ McGovern Medical School, and Memorial Hermann at Texas Medical Center, Houston, TX 77030, USA \\ Correspondence to: Jay-Jiguang Zhu, email: jay.jiguang.zhu@uth.tmc.edu \\ Keywords: glioblastoma (GBM), temozolomide, bevacizumab, overall survival, cancer registry \\ Received: November 23, $2016 \quad$ Accepted: March 20, $2017 \quad$ Published: April 12, 2017 \\ Copyright: Zhu et al. This is an open-access article distributed under the terms of the Creative Commons Attribution License 3.0 \\ (CC BY 3.0), which permits unrestricted use, distribution, and reproduction in any medium, provided the original author and source \\ are credited.
}

\section{ABSTRACT}

Few population-based analyses have investigated survival change in glioblastoma multiforme (GBM) patients treated with concomitant radiotherapy-temozolomide (RTTMZ) and adjuvant temozolomide (TMZ) and then bevacizumab (BEV) after Food and Drug Administration (FDA) approval, respectively. We aimed to explore the effects on survival with RT-TMZ, adjuvant TMZ and BEV in general GBM population based on the Surveillance, Epidemiology, and End Results (SEER) and Texas Cancer Registry (TCR) databases. A total of 28933 GBM patients from SEER $(N=24578)$ and TCR $(N=4355)$ between January 2000 and December 2013 were included. Patients were grouped into three calendar periods based on date of diagnosis: pre-RT-TMZ and pre-BEV (1/2000-2/2005, P1), post-RT-TMZ and pre-BEV (3/2005-4/2009, P2), and post-RT-TMZ and post-BEV (5/2009-12/2013, P3). The association between calendar period of diagnosis and survival was analyzed in SEER and TCR, separately, by the Kaplan-Meier method and Cox proportional hazards model. We found a significant increase in median overall survival (OS) across the three periods in both populations. In multivariate models, the risk of death was significantly reduced during P2 and further decreased in P3, which remained unchanged after stratification. Comparison and validation analysis were performed in the combined dataset, and consistent results were observed. We conclude that the OS of GBM patients in a "real-world" setting has been steadily improved from January 2000 to December 2013, which likely resulted from the administrations of TMZ concomitant with RT and adjuvant TMZ for newly diagnosed GBM and then BEV for recurrent GBM after respective FDA approval.

\section{INTRODUCTION}

Glioblastoma multiforme (GBM) comprises approximately $46.1 \%$ of primary malignant brain tumors, and only about $5.1 \%$ of patients survive five years after diagnosis [1]. Favorable clinical prognostic factors include maximum safe resection, good performance status, young age at diagnosis, completion of radiation and chemotherapies [1], [2], [3], [4]. Molecular prognostic factors include the presence of the $\mathrm{O}^{6}$-methylguanine-
DNA methyltransferase $(M G M T)$ promoter methylation [5], [6], the isocitrate dehydrogenase 1 and $2($ IDH1/2) mutations [7]. Besides the known hyper-methylation of the MGMT gene, Noushmehr et al [8] revealed that glioma cytosine-phosphate-guanine islands methylator phenotype (G-CIMP) is a positive prognostic marker. Furthermore, two studies have categorized GBM into 3 subtypes [mesenchymal (Mes), proneural ( $\mathrm{PN})$ and proliferative] [9], or 4 subtypes (Mes, PN, neuronal and classical) [10], respectively. Among all the subtypes of 
GBM, Phillips et al [9] found that PN GBM patients has the best prognosis.

Stupp and colleagues from the European Organization for Research and Treatment of Cancer (EORTC) Brain Tumor and Radiotherapy Groups and the National Cancer Institute of Canada (NCIC) Clinical Trials Group demonstrated that median overall survival (OS) of GBM patients improved to 14.6 months with concurrent radiation therapy and temozolomide (RTTMZ) followed by TMZ alone for 6 cycles in a phase III randomized controlled trial (RCT) published in March 2005 [11]. On March 15, 2005, the U.S. Food and Drug Administration (FDA) approved TMZ, an oral alkylating agent, in concurrent usage with RT followed by maintenance treatment with TMZ as a new standard of care (SOC) for newly diagnosed adult GBM [12]. For patients with recurrent GBM prior to FDA approval of bevacizumab (BEV), various therapies had been applied including second craniotomy with or without carmustine implantation (Gliadel wafers), salvage radiation, dosedense TMZ, nitrosoureas, carboplatin, PCV (procarbazine, lomustine and vincristine), etoposide or irinotecan [13], [14], [15], [16]. Based on the results of two phase II trials by Friedman et al (AVF3708g) [17] and Kreisl at al (National Cancer Institute 06-C-0064E) [18], BEV, a humanized monoclonal antibody against the vascular endothelial growth factor (VEGF), received accelerated approval for recurrent GBM therapy by FDA on May 9, 2009 [19].

It is known that GBM patients enrolled in RCTs have better prognosis and longer survival than those who were not enrolled in clinical trials [20]. Participants in clinical trials need to pass stringent selection criteria, including good performance status, satisfactory laboratory parameters, minimal comorbidity, normal organ status, and adequate bone marrow function [11], [17], [18]. Therefore, the impacts of RT-TMZ followed by TMZ and subsequently BEV for recurrent GBM on survival in a " real-world' setting" should be further investigated. Four population-based studies concluded that the usage of TMZ [21], [22], [23], [24] was associated with improved GBM survival based on the Surveillance, Epidemiology, and End Results (SEER) Program database. The time periods of GBM diagnosis studied in these four studies were 1993-2007, 2000-2006, 2001-2007 and 2000-2008, respectively. One limitation of the SEER database is the absence of individual patient's chemotherapy information. Dubrow et al [25] demonstrated that application of TMZ can fully explain the improved OS among GBM patients diagnosed between 1997 and 2008 from the Veterans Health Administration (VHA) dataset which had the access to individual chemotherapy data.

The impact of BEV on progression-free survival (PFS) and OS for newly diagnosed GBM has been investigated by two separate phase III RCTs. Chinot et al (AVAglio) [26] and Gilbert et al (RTOG 0825) [27] demonstrated that application of BEV during RT-TMZ period does not improve OS in newly diagnosed GBM patients compared to the control arms, independently. But they cannot conclude whether BEV therapy was beneficial to GBM patients or not overall, since patients from the control arms received BEV as well after GBM progression. Two population-based studies reported positive impact of BEV on OS of GBM patients by utilizing the SEER database [28], [29]. But there are limitations in those two studies: 1) Both of them performed analyses with limited follow up durations; 2) The usage of BEV was estimated based on three years of death records (2006, 2008 and 2010) from Johnson et al report [28]; 3) A limited number of GBM patients diagnosed between 2000 and 2009 was studied in Wachtel et al study [29]. In our opinion, they may not achieve a meaningful comparison of OS between pre-and post-BEV eras since BEV was approved by FDA on May 9, 2009. Therefore, further investigations related to the role of BEV on survival in "real-world" GBM population are needed.

In the present study, we constructed a retrospective cohort of patients diagnosed with GBM between January 2000 and December 2013 derived from the SEER, TCR and a pooled data from both SEER and TCR. We aim to test the hypotheses that the administration of TMZ and BEV after FDA approval, respectively, would explain the improved survival in GBM patients across three calendar periods of diagnosis, and the findings in SEER, TCR and the combined dataset would be consistent.

\section{RESULTS}

\section{Patients demographic and clinical characteristics in SEER and TCR datasets}

Table 1 shows the demographic and clinical features of grouped GBM patients at diagnosis. A total of 24578 GBM patients were extracted from the SEER dataset, and $21364(86.9 \%)$ of them died during the observation period between January 2000 and December 2013. From the TCR database, 3779 (86.8\%) GBM patients deceased within the same period in a total of 4355 patients identified. The majority of patients were more than 50 years old at diagnosis with mean \pm standard deviation (SD): SEER, $61.2 \pm 12.9$ years; TCR, $60.6 \pm 13.0$ years, respectively, and with male (SEER: 58.7\%, TCR: 59.9\%) and Caucasian (SEER: $80.4 \%$, TCR: $75.2 \%$ ) predominate.

Most patients received surgery (SEER: 81.3\%, TCR: $82.7 \%$ ) and adjuvant radiation (SEER: $81.1 \%$, TCR: $69.4 \%$ ) as their first-line treatments. The proportion of each baseline characteristic except for sex was significantly different across the three calendar periods of diagnosis in SEER. For TCR, the distributions of age at diagnosis, race/ethnicity and radiation status differed significantly across P1, P2 and P3. Within each calendar period of diagnosis, the distributions of several factors 
Table 1: Baseline characteristics of GBM patients from SEER, TCR and the combined dataset, by calendar period of diagnosis

\begin{tabular}{|c|c|c|c|c|c|c|c|c|c|c|c|c|c|c|c|c|c|c|}
\hline \multirow[b]{2}{*}{ Characteristics } & \multicolumn{4}{|c|}{ Jan 2000-Feb 2005 (P1) } & \multicolumn{4}{|c|}{ Mar 2005-Apr 2009 (P2) } & \multicolumn{4}{|c|}{ May 2009-Dec 2013 (P3) } & \multicolumn{4}{|c|}{ Total (P1, P2 and P3) } & \multirow[b]{2}{*}{$P^{e}$} & \multirow[b]{2}{*}{$P^{\mathrm{f}}$} \\
\hline & $\begin{array}{c}\text { SEER } \\
N=8169\end{array}$ & $\begin{array}{c}\text { TCR } \\
\mathbf{N}=1357\end{array}$ & $\begin{array}{c}\text { Combined } \\
\mathrm{N}=9526\end{array}$ & $P^{\mathrm{a}}$ & $\begin{array}{c}\text { SEER } \\
\mathbf{N}=\mathbf{7 4 2 0}\end{array}$ & $\begin{array}{c}\text { TCR } \\
\mathbf{N}=1286\end{array}$ & $\begin{array}{c}\text { Combined } \\
\mathrm{N}=8706\end{array}$ & $P^{b}$ & $\begin{array}{c}\text { SEER } \\
\mathbf{N}=8989\end{array}$ & $\begin{array}{c}\text { TCR } \\
\mathrm{N}=1712\end{array}$ & $\begin{array}{c}\text { Combined } \\
\mathrm{N}=10701\end{array}$ & $P^{\mathrm{c}}$ & $\begin{array}{c}\text { SEER } \\
\mathbf{N}=\mathbf{2 4 5 7 8}\end{array}$ & $\begin{array}{c}\text { TCR } \\
\mathbf{N}=4355\end{array}$ & $\begin{array}{c}\text { Combined } \\
\mathbf{N}=\mathbf{2 8 9 3 3}\end{array}$ & $P^{\mathrm{d}}$ & & \\
\hline \multicolumn{19}{|c|}{ Age at diagnosis, $\mathrm{N}(\%)$} \\
\hline $20-49$ & $\begin{array}{l}1660 \\
(20.3)\end{array}$ & $\begin{array}{c}273 \\
(20.1)\end{array}$ & $\begin{array}{c}1933 \\
(20.3)\end{array}$ & $<0.001$ & $\begin{array}{c}1310 \\
(17.7)\end{array}$ & $\begin{array}{c}238 \\
(18.5)\end{array}$ & $\begin{array}{l}1548 \\
(17.8)\end{array}$ & 0.832 & $\begin{array}{l}1409 \\
(15.7)\end{array}$ & $\begin{array}{c}290 \\
(16.9)\end{array}$ & $\begin{array}{c}1699 \\
(15.9)\end{array}$ & 0.231 & $\begin{array}{l}4379 \\
(17.8)\end{array}$ & $\begin{array}{c}801 \\
(18.4)\end{array}$ & $\begin{array}{c}5180 \\
(17.9)\end{array}$ & 0.008 & $<0.001$ & 0.001 \\
\hline $50-59$ & $\begin{array}{l}2004 \\
(24.5)\end{array}$ & $\begin{array}{c}399 \\
(29.4)\end{array}$ & $\begin{array}{c}2403 \\
(25.2)\end{array}$ & & $\begin{array}{l}2010 \\
(27.1)\end{array}$ & $\begin{array}{c}341 \\
(26.5)\end{array}$ & $\begin{array}{l}2351 \\
(27.0)\end{array}$ & & $\begin{array}{l}2270 \\
(25.3)\end{array}$ & $\begin{array}{c}433 \\
(25.3)\end{array}$ & $\begin{array}{l}2703 \\
(25.3)\end{array}$ & & $\begin{array}{l}6284 \\
(25.6)\end{array}$ & $\begin{array}{c}1173 \\
(26.9)\end{array}$ & $\begin{array}{l}7457 \\
(25.8)\end{array}$ & & & \\
\hline $60-69$ & $\begin{array}{l}2097 \\
(25.7)\end{array}$ & $\begin{array}{c}359 \\
(26.5)\end{array}$ & $\begin{array}{l}2456 \\
(25.8)\end{array}$ & & $\begin{array}{l}2091 \\
(28.2)\end{array}$ & $\begin{array}{c}353 \\
(27.5)\end{array}$ & $\begin{array}{l}2444 \\
(28.1)\end{array}$ & & $\begin{array}{l}2852 \\
(31.7)\end{array}$ & $\begin{array}{c}558 \\
(32.6)\end{array}$ & $\begin{array}{l}3410 \\
(31.9)\end{array}$ & & $\begin{array}{l}7040 \\
(28.6)\end{array}$ & $\begin{array}{l}1270 \\
(29.2)\end{array}$ & $\begin{array}{l}8310 \\
(28.7)\end{array}$ & & & \\
\hline $70-$ & $\begin{array}{l}2408 \\
(29.5)\end{array}$ & $\begin{array}{c}326 \\
(24.0)\end{array}$ & $\begin{array}{c}2734 \\
(28.7)\end{array}$ & & $\begin{array}{l}2009 \\
(27.1)\end{array}$ & $\begin{array}{c}354 \\
(27.5)\end{array}$ & $\begin{array}{l}2363 \\
(27.1)\end{array}$ & & $\begin{array}{l}2458 \\
(27.3)\end{array}$ & $\begin{array}{c}431 \\
(25.2)\end{array}$ & $\begin{array}{l}2889 \\
(27.0)\end{array}$ & & $\begin{array}{c}6875 \\
(28.0)\end{array}$ & $\begin{array}{c}1111 \\
(25.5)\end{array}$ & $\begin{array}{c}7986 \\
(27.6)\end{array}$ & & & \\
\hline \multicolumn{19}{|l|}{ Sex, N (\%) } \\
\hline Male & $\begin{array}{l}4825 \\
(59.1)\end{array}$ & $\begin{array}{c}818 \\
(60.3)\end{array}$ & $\begin{array}{c}5643 \\
(59.2)\end{array}$ & 0.399 & $\begin{array}{l}4388 \\
(59.1)\end{array}$ & $\begin{array}{c}784 \\
(61.0)\end{array}$ & $\begin{array}{c}5172 \\
(59.4)\end{array}$ & 0.218 & $\begin{array}{c}5219 \\
(58.1)\end{array}$ & $\begin{array}{c}1005 \\
(58.7)\end{array}$ & $\begin{array}{c}6224 \\
(58.2)\end{array}$ & 0.621 & $\begin{array}{l}14432 \\
(58.7)\end{array}$ & $\begin{array}{c}2607 \\
(59.9)\end{array}$ & $\begin{array}{l}17039 \\
(58.9)\end{array}$ & 0.158 & 0.279 & 0.426 \\
\hline Female & $\begin{array}{l}3344 \\
(40.9)\end{array}$ & $\begin{array}{c}539 \\
(39.7)\end{array}$ & $\begin{array}{l}3883 \\
(40.8)\end{array}$ & & $\begin{array}{l}3032 \\
(40.9)\end{array}$ & $\begin{array}{c}502 \\
(39.0)\end{array}$ & $\begin{array}{c}3534 \\
(40.6)\end{array}$ & & $\begin{array}{c}3770 \\
(41.9)\end{array}$ & $\begin{array}{c}707 \\
(41.3)\end{array}$ & $\begin{array}{l}4477 \\
(41.8)\end{array}$ & & $\begin{array}{l}10146 \\
(41.3)\end{array}$ & $\begin{array}{c}1748 \\
(40.1)\end{array}$ & $\begin{array}{l}11894 \\
(41.1)\end{array}$ & & & \\
\hline \multicolumn{19}{|c|}{ Race/Ethnicity, N (\%) } \\
\hline White & $\begin{array}{l}6735 \\
(82.4)\end{array}$ & $\begin{array}{c}1074 \\
(79.1)\end{array}$ & $\begin{array}{c}7809 \\
(82.0)\end{array}$ & $<0.001$ & $\begin{array}{c}5957 \\
(80.3)\end{array}$ & $\begin{array}{c}980 \\
(76.2)\end{array}$ & $\begin{array}{c}6937 \\
(79.7)\end{array}$ & $<0.001$ & $\begin{array}{l}7076 \\
(78.7)\end{array}$ & $\begin{array}{c}1220 \\
(71.3)\end{array}$ & $\begin{array}{c}8296 \\
(77.5)\end{array}$ & $<0.001$ & $\begin{array}{l}19768 \\
(80.4)\end{array}$ & $\begin{array}{l}3274 \\
(75.2)\end{array}$ & $\begin{array}{l}23042 \\
(79.6)\end{array}$ & $<0.001$ & $<0.001$ & $<0.001$ \\
\hline Black & $\begin{array}{l}415 \\
(5.1)\end{array}$ & $\begin{array}{c}72 \\
(5.3)\end{array}$ & $\begin{array}{l}487 \\
(5.1)\end{array}$ & & $\begin{array}{c}394 \\
(5.3)\end{array}$ & $\begin{array}{l}87 \\
(6.8)\end{array}$ & $\begin{array}{l}481 \\
(5.5)\end{array}$ & & $\begin{array}{c}532 \\
(5.9)\end{array}$ & $\begin{array}{l}110 \\
(6.4)\end{array}$ & $\begin{array}{l}642 \\
(6.0)\end{array}$ & & $\begin{array}{l}1341 \\
(5.5)\end{array}$ & $\begin{array}{l}269 \\
(6.2)\end{array}$ & $\begin{array}{l}1610 \\
(5.6)\end{array}$ & & & \\
\hline Hispanic & $\begin{array}{c}697 \\
(8.5)\end{array}$ & $\begin{array}{c}196 \\
(14.4)\end{array}$ & $\begin{array}{l}893 \\
(9.4)\end{array}$ & & $\begin{array}{c}747 \\
(10.1)\end{array}$ & $\begin{array}{c}197 \\
(15.3)\end{array}$ & $\begin{array}{c}944 \\
(10.8)\end{array}$ & & $\begin{array}{c}900 \\
(10.0)\end{array}$ & $\begin{array}{c}322 \\
(18.8)\end{array}$ & $\begin{array}{c}1222 \\
(11.4)\end{array}$ & & $\begin{array}{l}2344 \\
(9.5)\end{array}$ & $\begin{array}{c}715 \\
(16.4)\end{array}$ & $\begin{array}{c}3059 \\
(10.6)\end{array}$ & & & \\
\hline Others & $\begin{array}{c}322 \\
(3.9)\end{array}$ & $15(1.1)$ & $\begin{array}{l}337 \\
(3.5)\end{array}$ & & $\begin{array}{l}322 \\
(4.3)\end{array}$ & $\begin{array}{c}22 \\
(1.7)\end{array}$ & $\begin{array}{c}344 \\
(4.0)\end{array}$ & & $\begin{array}{c}481 \\
(5.4)\end{array}$ & $60(3.5)$ & $\begin{array}{c}541 \\
(5.1)\end{array}$ & & $\begin{array}{l}1125 \\
(4.6)\end{array}$ & $\begin{array}{c}97 \\
(2.2)\end{array}$ & $\begin{array}{l}1222 \\
(4.2)\end{array}$ & & & \\
\hline \multicolumn{19}{|c|}{ Marital status, N (\%) } \\
\hline Single & $\begin{array}{c}953 \\
(11.7)\end{array}$ & $\begin{array}{c}173 \\
(12.8)\end{array}$ & $\begin{array}{c}1126 \\
(11.8)\end{array}$ & 0.021 & $\begin{array}{c}963 \\
(13.0)\end{array}$ & $\begin{array}{c}164 \\
(12.8)\end{array}$ & $\begin{array}{l}1127 \\
(12.9)\end{array}$ & 0.119 & $\begin{array}{c}1343 \\
(14.9)\end{array}$ & $\begin{array}{c}272 \\
(15.9)\end{array}$ & $\begin{array}{c}1615 \\
(15.1)\end{array}$ & 0.261 & $\begin{array}{l}3259 \\
(13.3)\end{array}$ & $\begin{array}{c}609 \\
(14.0)\end{array}$ & $\begin{array}{c}3868 \\
(13.4)\end{array}$ & 0.001 & $<0.001$ & 0.068 \\
\hline Married & $\begin{array}{l}5582 \\
(68.3)\end{array}$ & $\begin{array}{c}955 \\
(70.4)\end{array}$ & $\begin{array}{l}6537 \\
(68.6)\end{array}$ & & $\begin{array}{l}5062 \\
(68.2)\end{array}$ & $\begin{array}{c}910 \\
(70.8)\end{array}$ & $\begin{array}{l}5972 \\
(68.6)\end{array}$ & & $\begin{array}{l}6027 \\
(67.1)\end{array}$ & $\begin{array}{l}1157 \\
(67.6)\end{array}$ & $\begin{array}{c}7184 \\
(67.1)\end{array}$ & & $\begin{array}{l}16671 \\
(67.8)\end{array}$ & $\begin{array}{l}3022 \\
(69.4)\end{array}$ & $\begin{array}{l}19693 \\
(68.1)\end{array}$ & & & \\
\hline DWS & $\begin{array}{c}1634 \\
(20.0)\end{array}$ & $\begin{array}{c}229 \\
(16.9)\end{array}$ & $\begin{array}{c}1863 \\
(19.6)\end{array}$ & & $\begin{array}{l}1395 \\
(18.8)\end{array}$ & $\begin{array}{c}212 \\
(16.5)\end{array}$ & $\begin{array}{l}1607 \\
(18.5)\end{array}$ & & $\begin{array}{c}1619 \\
(18.0)\end{array}$ & $\begin{array}{c}283 \\
(16.5)\end{array}$ & $\begin{array}{c}1902 \\
(17.8)\end{array}$ & & $\begin{array}{l}4648 \\
(18.9)\end{array}$ & $\begin{array}{c}724 \\
(16.6)\end{array}$ & $\begin{array}{c}5372 \\
(18.6)\end{array}$ & & & \\
\hline \multicolumn{19}{|l|}{ Tumor site, N (\%) } \\
\hline Supratentorial & $\begin{array}{l}6137 \\
(75.1)\end{array}$ & $\begin{array}{l}1072 \\
(79.0)\end{array}$ & $\begin{array}{l}7209 \\
(75.7)\end{array}$ & 0.002 & $\begin{array}{l}5832 \\
(78.6)\end{array}$ & $\begin{array}{c}1023 \\
(79.6)\end{array}$ & $\begin{array}{l}6855 \\
(78.7)\end{array}$ & 0.442 & $\begin{array}{l}7036 \\
(78.3)\end{array}$ & $\begin{array}{c}1328 \\
(77.6)\end{array}$ & $\begin{array}{l}8364 \\
(78.2)\end{array}$ & 0.519 & $\begin{array}{l}19005 \\
(77.3)\end{array}$ & $\begin{array}{l}3423 \\
(78.6)\end{array}$ & $\begin{array}{l}22428 \\
(77.5)\end{array}$ & 0.063 & $<0.001$ & 0.388 \\
\hline $\begin{array}{l}\text { Infratentorial/ } \\
\text { NOS }\end{array}$ & $\begin{array}{l}2032 \\
(24.9)\end{array}$ & $\begin{array}{c}285 \\
(21.0)\end{array}$ & $\begin{array}{l}2317 \\
(24.3)\end{array}$ & & $\begin{array}{c}1588 \\
(21.4)\end{array}$ & $\begin{array}{c}263 \\
(20.5)\end{array}$ & $\begin{array}{l}1851 \\
(21.3)\end{array}$ & & $\begin{array}{l}1953 \\
(21.7)\end{array}$ & $\begin{array}{c}384 \\
(22.4)\end{array}$ & $\begin{array}{l}2337 \\
(21.8)\end{array}$ & & $\begin{array}{l}5573 \\
(22.7)\end{array}$ & $\begin{array}{c}932 \\
(21.4)\end{array}$ & $\begin{array}{l}6505 \\
(22.5)\end{array}$ & & & \\
\hline \multicolumn{19}{|l|}{ Surgery, N (\%) } \\
\hline No surgery & $\begin{array}{l}1683 \\
(20.6)\end{array}$ & $\begin{array}{c}244 \\
(18.0)\end{array}$ & $\begin{array}{l}1927 \\
(20.2)\end{array}$ & 0.001 & $\begin{array}{c}1475 \\
(19.9)\end{array}$ & $\begin{array}{c}216 \\
(16.8)\end{array}$ & $\begin{array}{l}1691 \\
(19.4)\end{array}$ & 0.007 & $\begin{array}{c}1438 \\
(16.0)\end{array}$ & $\begin{array}{c}293 \\
(17.1)\end{array}$ & $\begin{array}{l}1731 \\
(16.2)\end{array}$ & 0.021 & $\begin{array}{l}4596 \\
(18.7)\end{array}$ & $\begin{array}{c}753 \\
(17.3)\end{array}$ & $\begin{array}{l}5349 \\
(18.5)\end{array}$ & $<0.001$ & $<0.001$ & 0.315 \\
\hline $\begin{array}{l}\text { Local excision/ } \\
\text { biopsy }\end{array}$ & $\begin{array}{r}1499 \\
(18.4)\end{array}$ & $\begin{array}{c}288 \\
(21.2)\end{array}$ & $\begin{array}{l}1787 \\
(18.8)\end{array}$ & & $\begin{array}{l}1433 \\
(19.3)\end{array}$ & $\begin{array}{c}260 \\
(20.2)\end{array}$ & $\begin{array}{l}1693 \\
(19.4)\end{array}$ & & $\begin{array}{l}1940 \\
(21.6)\end{array}$ & $\begin{array}{c}329 \\
(19.2)\end{array}$ & $\begin{array}{l}2269 \\
(21.2)\end{array}$ & & $\begin{array}{c}4872 \\
(19.8)\end{array}$ & $\begin{array}{c}877 \\
(20.1)\end{array}$ & $\begin{array}{c}5749 \\
(19.9)\end{array}$ & & & \\
\hline $\begin{array}{l}\text { Partial } \\
\text { resection }\end{array}$ & $\begin{array}{l}2320 \\
(28.4)\end{array}$ & $\begin{array}{c}344 \\
(25.4)\end{array}$ & $\begin{array}{l}2664 \\
(28.0)\end{array}$ & & $\begin{array}{l}2035 \\
(27.4)\end{array}$ & $\begin{array}{c}330 \\
(25.7)\end{array}$ & $\begin{array}{l}2365 \\
(27.2)\end{array}$ & & $\begin{array}{l}2718 \\
(30.2)\end{array}$ & $\begin{array}{c}490 \\
(28.6)\end{array}$ & $\begin{array}{l}3208 \\
(30.0)\end{array}$ & & $\begin{array}{l}7073 \\
(28.8)\end{array}$ & $\begin{array}{l}1164 \\
(26.7)\end{array}$ & $\begin{array}{l}8237 \\
(28.5)\end{array}$ & & & \\
\hline GTR & $\begin{array}{l}2667 \\
(32.7)\end{array}$ & $\begin{array}{c}481 \\
(35.5)\end{array}$ & $\begin{array}{l}3148 \\
(33.0)\end{array}$ & & $\begin{array}{l}2477 \\
(33.4)\end{array}$ & $\begin{array}{c}480 \\
(37.3)\end{array}$ & $\begin{array}{l}2957 \\
(34.0)\end{array}$ & & $\begin{array}{l}2893 \\
(32.2)\end{array}$ & $\begin{array}{c}600 \\
(35.1)\end{array}$ & $\begin{array}{c}3493 \\
(32.6)\end{array}$ & & $\begin{array}{c}8037 \\
(32.7)\end{array}$ & $\begin{array}{c}1561 \\
(35.8)\end{array}$ & $\begin{array}{l}9598 \\
(33.2)\end{array}$ & & & \\
\hline \multicolumn{19}{|l|}{ Radiation, N (\%) } \\
\hline Untreated & $\begin{array}{c}1659 \\
(20.3)\end{array}$ & $\begin{array}{c}261 \\
(19.2)\end{array}$ & $\begin{array}{l}1920 \\
(20.2)\end{array}$ & 0.361 & $\begin{array}{c}1425 \\
(19.2)\end{array}$ & $\begin{array}{c}388 \\
(30.2)\end{array}$ & $\begin{array}{l}1813 \\
(20.8)\end{array}$ & $<0.001$ & $\begin{array}{l}1565 \\
(17.4)\end{array}$ & $\begin{array}{c}683 \\
(39.9)\end{array}$ & $\begin{array}{l}2248 \\
(21.0)\end{array}$ & $<0.001$ & $\begin{array}{l}4649 \\
(18.9)\end{array}$ & $\begin{array}{l}1332 \\
(30.6)\end{array}$ & $\begin{array}{l}5981 \\
(20.7)\end{array}$ & $<0.001$ & $<0.001$ & $<0.001$ \\
\hline Treated & $\begin{array}{c}6510 \\
(79.7)\end{array}$ & $\begin{array}{c}1096 \\
(80.8)\end{array}$ & $\begin{array}{c}7606 \\
(79.8)\end{array}$ & & $\begin{array}{c}5995 \\
(80.8)\end{array}$ & $\begin{array}{c}898 \\
(69.8)\end{array}$ & $\begin{array}{c}6893 \\
(79.2)\end{array}$ & & $\begin{array}{c}7424 \\
(82.6)\end{array}$ & $\begin{array}{c}1029 \\
(60.1)\end{array}$ & $\begin{array}{c}8453 \\
(79.0)\end{array}$ & & $\begin{array}{l}19929 \\
(81.1)\end{array}$ & $\begin{array}{c}3023 \\
(69.4)\end{array}$ & $\begin{array}{l}22952 \\
(79.3)\end{array}$ & & & \\
\hline
\end{tabular}

Abbreviation: DWS, divorced or widowed or separated; NOS, not otherwise specified; GTR, gross total resection.

a, b, c and d: Pearson's $\chi 2$ test was conducted to compare the proportions of baseline characteristics between SEER and TCR within P1, P2 and P3, respectively.

$\mathrm{e}$ and f: Pearson's $\chi 2$ test were conducted to compare the proportions of baseline characteristics across calendar period of diagnosis in SEER and TCR, respectively. 
varied significantly between SEER and TCR: P1, age at diagnosis $(P<0.001)$, race/ethnicity $(P<0.001)$, marital status $(P=0.021)$, tumor site $(P=0.002)$ and surgery $(P=$ $0.001)$; P2, race/ethnicity $(P<0.001)$, surgery $(P=0.007)$ and radiation $(P<0.001)$; $\mathrm{P} 3$, race/ethnicity $(P<0.001)$, surgery $(P=0.021)$ and radiation $(P<0.001)$.

\section{Survival results in SEER, TCR and the combined dataset}

As shown in Table 2, the median OS for P1, P2 and P3 were 8, 10 and 11 months in SEER (log-rank test, $P$ $<0.001), 9,10$ and 11 months in TCR (log-rank test, $P<$ 0.001 ), and 8,10 and 11 months in the combined dataset (log-rank test, $P<0.001$ ), respectively. The differences in OS of P1 versus P2 (log-rank test, $P<0.001$ ), P1 versus P3 (log-rank test, $P<0.001$ ), and P2 versus P3 (log-rank test, $P<0.001)$ were statistically significant in SEER and the combined dataset. Analysis of the TCR dataset revealed a significant improved survival from $\mathrm{P} 1$ to $\mathrm{P} 2$, and from P1 to P3, but no significant effect from P2 to P3 was detected (log-rank test, $P=0.833$ ).

After performing Chi-square test with Schouten correction, 1-year survival rate increased significantly over the three calendar periods and reached a peak in P3 in SEER (P1: 33.6\%, P2: 42.1\%, and P3: 45.1\%; $P$ $<0.001$ for P1 versus P2, P1 versus P3, and P2 versus $\mathrm{P} 3$ ) and the combined dataset (P1: $34.0 \%$, P2: 42.2\%, and P3: $45.0 \% ; P<0.001$ for $\mathrm{P} 1$ versus $\mathrm{P} 2, \mathrm{P} 1$ versus P3, and P2 versus P3). For the TCR dataset, a significant improvement was found in 1-year survival rate from $\mathrm{P} 1$ to P2 (P1: 36.1\%, P2: 42.5\%; $P<0.001$ for P1 versus P2), from P1 to P3 (P1: 36.1\%, P3: 44.5\%; log-rank test, $P<$ 0.001 for $\mathrm{P} 1$ versus $\mathrm{P} 3)$, but no significant survival rate difference was observed from P2 to P3 (P2: 42.5\%, P3: $44.5 \% ; P=0.306$ for $\mathrm{P} 2$ versus $\mathrm{P} 3$ ). Interestingly, from $\mathrm{P} 1$ to $\mathrm{P} 2$, 2-year survival rate elevated significantly in SEER (P1: 12.6\%, P2: 18.8\%), TCR (P1: 13.3\%, P2: 20.4\%) and the combined dataset (P1: 12.7\%, P2: 19.1\%), while no significant difference in 2-year survival rate between P2 and P3 was found in all three datasets (Table 2).

Comparing survival functions between SEER and TCR, the results from the two datasets revealed no significant difference in P1 (log-rank test, $P=0.265$ ) and P2 (log-rank test, $P=0.874)$, but varied significantly in P3 (log-rank test, $P=0.021)$. The log-rank tests for a trend of OS over calendar period of diagnosis were significant in SEER, TCR and the combined dataset (Table 2 and Figure 1). Since the TCR dataset offers patients with longer follow-up period up to May 2015, we did a sub-analysis of the dataset including the extended follow-up period. It revealed a prolonged median OS in P3 (12.0 months) and significantly improved survival during P3 period (P2 versus P3, $P<0.001$ ) (Supplementary Table 2 and Supplementary Figure 1).
Table 3, Table 4 and Table 5 present the hazard ratios (HRs) and 95\% confidence intervals $(95 \% \mathrm{CI})$ from Cox proportional hazards regression models in SEER, TCR and the combined dataset, respectively. The HRs for calendar period of diagnosis did not change after controlling for different sets of covariates in multivariate models (Model 1, Model 2 and Model 3 for SEER and TCR; Model 1, Model 2, Model 3 and Model 4 for the combined dataset), except for the TCR dataset. Based on the analysis of the TCR database, the risk for death during P3 was higher than that of P2 in age-sex adjusted model, Model 1 and Model 2, but it decreased to 0.78 (HR: $0.78,95 \% \mathrm{CI}: 0.72-0.84)$ when adding surgery and radiation as shown in Model 3 (Table 4). With P1 serving as a reference group as shown in Model 3, there was a significant reduction of risks of death during P2 and P3 periods in SEER (P2, HR: 0.83, 95\% CI: 0.81-0.86; P3, HR: $0.77,95 \%$ CI: 0.74-0.79) and the combined dataset (P2, HR: 0.82, 95\% CI: 0.80-0.85; P3, HR: 0.76, 95\% CI: 0.73-0.78). For the combined dataset, we built up Model 4 by adding "cancer registries" in the covariates of Model 3, and found that the HRs during P2 and P3 were unchanged comparing results in Model 3. Additionally, the risks of death derived from age-sex adjusted model, Model 1, Model 2 and Model 3 remained stable in TCR with extended follow-up (Supplementary Table 3).

The crude Kaplan-Meier survival estimates and direct adjusted survival results based on Model 3 (SEER and TCR) or Model 4 (the combined dataset) are presented in Figure 1. Figure 2 and Figure 3 displayed survival curves stratified by age group at diagnosis. The trend and pattern of survival were consistent across three datasets, but the survival curve for P3 was nearly identical to that of P2 in TCR (Figure 1). After stratification by age group, survival distributions became worse with advancing age, but the improved survival across calendar periods was still preserved within each stratum of age groups in SEER and the combined dataset (Figure 2 and Figure 3). However, the survival curve during P2 was superior to that of P3 among the group of aged $\geq 70$ in TCR. Similar patterns of survival were observed in TCR with extended follow-up, except the survival curve during P3 which was identical to that of P2 in the elderly patients (aged $\geq 70$ ) (Supplementary Figure 2). In stratification analyses by age at diagnosis, tumor site, surgery and radiation status, the decreased HR over calendar period within each stratum of stratified variables was observed in SEER, TCR, the combined dataset (Table 6) and TCR with extended follow-up (Supplementary Table 4). In addition, we have conducted a sub-analysis in an analytic cohort (aged $\geq$ 18 years old), and the results were consistent with the findings presented above (Data not shown). 
Table 2: Median OS, 1-year and 2-year survival rate by calendar period of diagnosis in SEER, TCR and the combined dataset*

\begin{tabular}{|c|c|c|c|c|c|c|c|c|}
\hline \multirow{2}{*}{ Survival statistics } & \multicolumn{8}{|c|}{ Calendar Period of Diagnosis } \\
\hline & $\begin{array}{c}\text { Jan } 2000 \text { - Feb } 2005 \\
\text { (P1) }\end{array}$ & Mar 2005 - Apr 2009 (P2) & May 2009 - Dec 2013 (P3) & $\begin{array}{c}\text { Total } \\
\text { (P1, P2 and P3) }\end{array}$ & P1 vs P2 & P1 vs P3 & P2 vs P3 & Trend Test \\
\hline SEER & & & & & $P^{a}$ & $P^{b}$ & $P^{c}$ & $P^{d}$ \\
\hline Total cases, $\mathrm{N}$ & 8169 & 7420 & 8989 & 24578 & $<0.001$ & $<0.001$ & $<0.001$ & $<0.001$ \\
\hline Death cases, N (\%) & $7960(97.4)$ & 7045 (94.9) & $6359(70.7)$ & $21364(86.9)$ & & & & \\
\hline Median OS (months, IQR) & $8.0(3.0-16.0)$ & $10.0(4.0-20.0)$ & $11.0(4.0-21.0)$ & $10.0(4.0-19.0)$ & & & & \\
\hline 1 -year survival rate, $\%(95 \% \mathrm{CI})$ & $33.6(32.6-34.7)$ & $42.1(41.0-43.3)$ & $45.1(43.9-46.2)$ & $40.0(39.4-40.6)$ & $<0.001$ & $<0.001$ & $<0.001$ & \\
\hline 2 -year survival rate, $\%(95 \% \mathrm{CI})$ & $12.6(11.9-13.4)$ & $18.8(17.9-19.7)$ & $19.8(18.7-20.9)$ & $16.6(16.1-17.1)$ & $<0.001$ & $<0.001$ & 0.070 & \\
\hline \multicolumn{9}{|l|}{ TCR } \\
\hline Total cases, $\mathrm{N}$ & 1357 & 1286 & 1712 & 4355 & $<0.001$ & $<0.001$ & 0.833 & $<0.001$ \\
\hline Death cases, N (\%) & $1318(97.1)$ & $1219(94.8)$ & $1242(72.5)$ & $3779(86.8)$ & & & & \\
\hline Median OS (months, IQR) & $9.0(4.0-16.0)$ & $10.0(4.0-20.9)$ & $11.0(4.0-20.0)$ & $10.0(4.0-19.0)$ & & & & \\
\hline 1 -year survival rate, $\%(95 \% \mathrm{CI})$ & $36.1(33.6-38.7)$ & $42.5(39.8-45.2)$ & $44.5(41.8-47.1)$ & $41.0(39.5-42.5)$ & $<0.001$ & $<0.001$ & 0.306 & \\
\hline 2 -year survival rate, $\%(95 \% \mathrm{CI})$ & $13.3(11.6-15.2)$ & $20.4(18.3-22.7)$ & $19.4(17.0-21.9)$ & $17.5(16.3-18.8)$ & $<0.001$ & $<0.001$ & 0.571 & \\
\hline \multicolumn{9}{|l|}{ The combined dataset } \\
\hline Total cases, $\mathrm{N}$ & 9526 & 8706 & 10701 & 28933 & $<0.001$ & $<0.001$ & $<0.001$ & $<0.001$ \\
\hline Death cases, N (\%) & $9278(97.4)$ & 8264 (94.9) & $7601(71.0)$ & $25143(86.9)$ & & & & \\
\hline Median OS (months, IQR) & $8.0(4.0-16.0)$ & $10.0(4.0-20.0)$ & $11.0(4.0-21.0)$ & $10.0(4.0-19.0)$ & & & & \\
\hline 1 -year survival rate, $\%(95 \% \mathrm{CI})$ & $34.0(33.0-34.9)$ & $42.2(41.2-43.2)$ & $45.0(43.9-46.0)$ & $40.2(39.6-40.7)$ & $<0.001$ & $<0.001$ & $<0.001$ & \\
\hline 2 -year survival rate, $\%(95 \% \mathrm{CI})$ & $12.7(12.1-13.4)$ & $19.1(18.2-19.9)$ & $19.8(18.8-20.8)$ & $16.8(16.3-17.2)$ & $<0.001$ & $<0.001$ & 0.150 & \\
\hline \multicolumn{9}{|l|}{ SEER vs TCR } \\
\hline Log-rank test, $P$ value & 0.265 & 0.874 & 0.021 & 0.657 & & & & \\
\hline
\end{tabular}

Abbreviation: OS, overall survival; IQR, interquartile range; $95 \% \mathrm{CI}$, $95 \%$ confidence interval.

*: Using log-rank test tested the differences in Kaplan-Meier survival functions across calendar periods of diagnosis.

a: $P$ value for comparison of survival functions, and two-sided Chi-square test with Schouten correction in 1-year or 2-year survival rate between P1 and P2 in SEER or TCR or the combined dataset.

$\mathrm{b}$ : $P$ value for comparison of survival functions, and two-sided Chi-square test with Schouten correction in 1-year or 2-year survival rate between P1 and P3 in SEER or TCR or the combined dataset.

c: $P$ value for comparison of survival functions, and two-sided Chi-square test with Schouten correction in 1-year or 2-year survival rate between P2 and P3 in SEER or TCR or the combined dataset.

d: Trend $P$ value for survival functions across P1, P2 and P3 in SEER or TCR or the combined dataset.

\section{DISCUSSION}

Prior analysis of RCTs [11], [30] and populationbased studies demonstrated that administration of TMZ significantly improved the OS for patients with GBM [21], [22], [23], [24], [25], [31]. Since FDA accelerated approval of BEV for progressive GBM on May 9, 2009, two SEER-based studies focused on the impact of BEV on OS in general GBM population [28], [29]. Both studies suggested that the addition of BEV to GBM treatment improved OS among GBM patients. However, the two studies had limited methods of categorizing patients and statistical analyses, limited number of GBM patients and short follow-up period after FDA approval of BEV. Therefore, more new investigations of general GBM patients in "real-world" setting with longer period of follow-up are needed to examine the effect of BEV on OS of GBM patients after FDA approval.

Our findings suggested that OS and 1-year survival rate improved significantly across calendar period of diagnosis in SEER, TCR and the combined dataset, except that the improved survival within P3 compared to $\mathrm{P} 2$ in TCR was not significant $(P=0.833)$. There was no survival benefit observed in 1-year or 2-year survival rate between $\mathrm{P} 2$ and $\mathrm{P} 3$ in TCR, nor 2-year survival rate between $\mathrm{P} 2$ and $\mathrm{P} 3$ in SEER and in the combined dataset. One explanation for the reduced survival in P3 comparing to P2 in TCR could be related to the lower proportion of patients received radiation during P3. The proportion of patients treated with radiation therapy in TCR decreased from $80.8 \%$ to $69.8 \%$ and to $60.1 \%$ in $\mathrm{P} 1, \mathrm{P} 2$, and $\mathrm{P} 3$, successively. However, when we did a sub-analysis of the extended follow-up of the TCR dataset up to May 2015, we found that the difference in survival between P2 and P3 was significant (Supplementary Figure 1 and Supplementary Table 2). This finding indicated that the survival benefit of BEV could be observed when given longer period of followup and that may compensate the loss of benefit with lower radiation proportion in P3. Another factor may contribute to the improved GBM survival observed in P3 with extended follow-up period was the availability of broader insurance coverage in Texas, which may translate to more applications of BEV in 2014 and 2015. 
Since the implementation of Affordable Care Act (ACA) Marketplace in Texas in January 2014, the uninsured rate in Texas dropped from $22.1 \%$ (2013) to $19.1 \%$ (2014), while the uninsured rate in Texas remained the highest across the nation. The uninsured rate nationally reduced from $14.5 \%$ (2013) to $11.7 \%$ (2014) [32], [33].

While analyzing the cohorts according to different age groups at diagnosis, we found that the survival benefit across P1, P2 and P3 decreased with increasing age: the patients at 20-49 years old group had the most improved survival in P3 comparing to P2, but the elderly GBM patients (age at diagnosis $\geq 70$ years old) showed limited OS benefit in SEER and even reduced survival in TCR from P2 to P3 periods. This diminished OS benefit along with advancing age is intriguing. It could be related to three possible explanations: first, for elderly patients (age at diagnosis $\geq 70$ years), physicians might not prescribe SOC due to relatively shorter life expectancy considering their ages and limited tolerance, and may apply to standard or short course radiation only with avoiding using TMZ or BEV or both. Second, IDH1/2 mutations occur more frequently in younger patients, and these patients have an improved OS than those with wild-type $I D H$ genes which is the case for nearly all de novo GBM of the elderly [34], [35]. However, these two reasons are less likely to be valid since there is no known evidence of changes of physician treatment routine for GBM patients except FDA approval of new therapies, nor gene pool alteration of GBM patients over the past 13 years. The third reason is the most likely explanation of this observation in our opinion. It is related to different mechanisms of GBM tumor pathogenesis and responses to BEV between young and elderly patients. By performing retrospective analysis of the AVAglio trial, Sandmann et al revealed that GBM patients with IDH1 mutation and PN subtype were more likely to obtain OS benefit from BEV therapy during first-line treatment [36]. Given the fact that elderly GBM patients are more likely to be $I D H 1$ wild-type and Mes subtype of GBM than younger patients [34], [35], [36], they may not draw survival benefit with BEV therapy as younger patients do (see P3, Figure 2, Figure 3 and Table 6). The disparity of deriving survival benefit from $\mathrm{BEV}$ in different age groups reminds us that personalized strategy of GBM treatment, such as drug selection, is critical for improving GBM patient's outcomes in the future.

The survival patterns between SEER and TCR were similar across calendar period of diagnosis in Figure 1, but differed significantly within P3 by applying the logrank test. This difference might be attributed to the smaller sample size, reduced proportion of radiation received in TCR population as mentioned above or other potential factors we cannot obtain detailed data in this study, including insurance coverage rate, socioeconomic status and access to health care resources in Texas versus the 18 regions of SEER registries [33]. Possible biological mechanisms for the impact of TMZ on the prolonging survival of GBM patients could be explained by the drugrelated alkylation of DNA which interferes with GBM cell
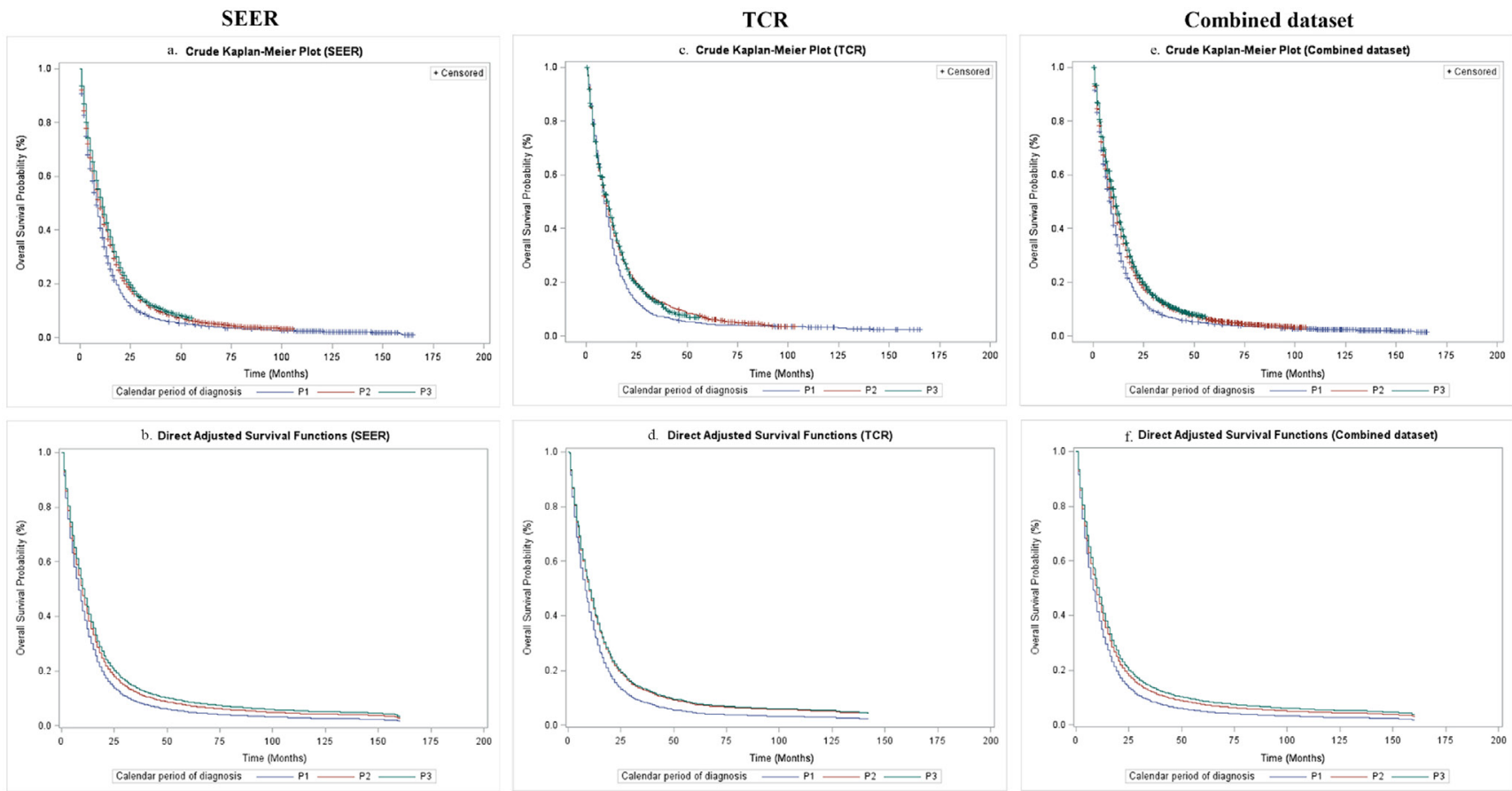

Figure 1: Overall survival of GBM patients by calendar period of diagnosis in SEER, TCR and the combined dataset. (a) Crude overall survival in SEER; (b) Direct adjusted survival after adjusting covariates in SEER; (c) Crude overall survival in TCR; (d) Direct adjusted survival after adjusting covariates in TCR; (e) Crude overall survival in the combined dataset; (f) Direct adjusted survival after adjusting covariates in the combined dataset. 
Table 3: Risk of death among GBM patients in relation to calendar period of diagnosis in SEER (N=24578)

\begin{tabular}{|c|c|c|c|c|c|c|c|c|c|c|}
\hline \multirow{2}{*}{ Predictors } & \multirow{2}{*}{$\frac{\text { Cases }}{\mathrm{N}}$} & \multirow{2}{*}{$\frac{\text { Death }}{\mathrm{N}}$} & \multicolumn{2}{|c|}{ Age-sex adjusted } & \multicolumn{2}{|c|}{ Model 1 ${ }^{\mathrm{a}}$} & \multicolumn{2}{|c|}{ Model $2^{b}$} & \multicolumn{2}{|c|}{ Model $3^{c}$} \\
\hline & & & HR & $95 \% \mathrm{CI}$ & HR & $95 \% \mathrm{CI}$ & HR & $95 \% \mathrm{CI}$ & HR & $95 \% \mathrm{CI}$ \\
\hline \multicolumn{11}{|l|}{ Calendar period of diagnosis } \\
\hline Jan 2000-Feb 2005 (P1) & 8169 & 7960 & 1.00 & - & 1.00 & - & 1.00 & - & 1.00 & - \\
\hline Mar 2005-Apr 2009 (P2) & 7420 & 7045 & 0.82 & $0.79-0.85$ & 0.82 & $0.79-0.85$ & 0.83 & $0.80-0.85$ & 0.83 & $0.81-0.86$ \\
\hline May 2009-Dec 2013 (P3) & 8989 & 6359 & 0.74 & $0.72-0.76$ & 0.74 & $0.72-0.77$ & 0.75 & $0.72-0.77$ & 0.77 & $0.74-0.79$ \\
\hline \multicolumn{11}{|l|}{ Age at diagnosis group } \\
\hline $20-49$ & 4379 & 3401 & 1.00 & - & 1.00 & - & 1.00 & - & 1.00 & - \\
\hline $50-59$ & 6284 & 5321 & 1.50 & $1.44-1.57$ & 1.51 & $1.44-1.58$ & 1.50 & $1.44-1.57$ & 1.50 & $1.44-1.57$ \\
\hline $60-69$ & 7040 & 6186 & 2.02 & $1.94-2.11$ & 2.03 & $1.94-2.12$ & 2.03 & $1.95-2.12$ & 2.00 & $1.92-2.09$ \\
\hline $70-$ & 6875 & 6456 & 3.41 & $3.27-3.56$ & 3.39 & $3.24-3.54$ & 3.39 & $3.24-3.54$ & 3.12 & $2.98-3.26$ \\
\hline \multicolumn{11}{|l|}{ Sex } \\
\hline Male & 14432 & 12531 & 1.00 & - & 1.00 & - & 1.00 & - & 1.00 & - \\
\hline Female & 10146 & 8833 & 0.97 & $0.94-0.99$ & 0.94 & $0.91-0.96$ & 0.94 & $0.91-0.96$ & 0.94 & $0.92-0.97$ \\
\hline \multicolumn{11}{|l|}{ Race/Ethnicity } \\
\hline White & 19768 & 17399 & & & 1.00 & - & 1.00 & - & 1.00 & - \\
\hline Black & 1341 & 1134 & & & 1.06 & $1.00-1.13$ & 1.06 & $0.99-1.12$ & 1.02 & $0.96-1.08$ \\
\hline Hispanic & 2344 & 1938 & & & 0.98 & $0.93-1.02$ & 0.97 & $0.92-1.02$ & 0.94 & $0.89-0.98$ \\
\hline Others & 1125 & 893 & & & 0.83 & $0.78-0.89$ & 0.82 & $0.77-0.88$ & 0.80 & $0.75-0.86$ \\
\hline \multicolumn{11}{|l|}{ Marital status } \\
\hline Single & 3259 & 2667 & & & 1.00 & - & 1.00 & - & 1.00 & - \\
\hline Married & 16671 & 14468 & & & 0.90 & $0.86-0.93$ & 0.89 & $0.86-0.93$ & 0.95 & $0.91-0.99$ \\
\hline DWS & 4648 & 4229 & & & 1.09 & $1.04-1.15$ & 1.09 & $1.04-1.15$ & 1.11 & $1.06-1.17$ \\
\hline \multicolumn{11}{|l|}{ Tumor site } \\
\hline Supratentorial & 19005 & 16380 & & & & & 1.00 & - & 1.00 & - \\
\hline Infratentorial/NOS & 5573 & 4984 & & & & & 1.24 & $1.20-1.28$ & 1.15 & $1.11-1.18$ \\
\hline \multicolumn{11}{|l|}{ Surgery } \\
\hline No surgery & 4596 & 4332 & & & & & & & 1.00 & - \\
\hline Local excision/biopsy & 4872 & 4295 & & & & & & & 0.61 & $0.58-0.63$ \\
\hline Partial resection & 7073 & 6111 & & & & & & & 0.65 & $0.63-0.68$ \\
\hline GTR & 8037 & 6626 & & & & & & & 0.49 & $0.47-0.51$ \\
\hline \multicolumn{11}{|l|}{ Radiation } \\
\hline Untreated & 4649 & 4386 & & & & & & & 1.00 & - \\
\hline Treated & 19929 & 16978 & & & & & & & 0.51 & $0.49-0.52$ \\
\hline
\end{tabular}

Abbreviation: DWS, divorced or widowed or separated; NOS, not otherwise specified; GTR, gross total resection; HR, hazard ratio; $95 \%$ CI, 95\% confidence interval.

a: Model 1: Adjusted age at diagnosis, sex, race/ethnicity and marital status.

b: Model 2: Adjusted age at diagnosis, sex, race/ethnicity, marital status and tumor site.

c: Model 3: Adjusted age at diagnosis, sex, race/ethnicity, marital status, tumor site, surgery and radiation. 
Table 4: Risk of death among GBM patients in relation to calendar period of diagnosis in TCR $(\mathrm{N}=4355)$

\begin{tabular}{|c|c|c|c|c|c|c|c|c|c|c|}
\hline \multirow{2}{*}{ Predictors } & \multirow{2}{*}{$\frac{\text { Cases }}{\mathbf{N}}$} & \multirow{2}{*}{$\frac{\text { Death }}{\mathrm{N}}$} & \multicolumn{2}{|c|}{ Age-sex adjusted } & \multicolumn{2}{|c|}{ Model 1 ${ }^{\mathrm{a}}$} & \multicolumn{2}{|c|}{ Model $2^{\text {b }}$} & \multicolumn{2}{|c|}{ Model $3^{c}$} \\
\hline & & & HR & $95 \%$ CI & HR & $95 \%$ CI & HR & $95 \% \mathrm{CI}$ & HR & $95 \%$ CI \\
\hline \multicolumn{11}{|l|}{ Calendar period of diagnosis } \\
\hline Jan 2000-Feb 2005 (P1) & 1357 & 1318 & 1.00 & - & 1.00 & - & 1.00 & - & 1.00 & - \\
\hline Mar 2005-Apr 2009 (P2) & 1286 & 1219 & 0.81 & $0.75-0.88$ & 0.81 & $0.75-0.88$ & 0.81 & $0.75-0.88$ & 0.79 & $0.73-0.86$ \\
\hline May 2009-Dec 2013 (P3) & 1712 & 1242 & 0.83 & $0.76-0.89$ & 0.83 & $0.77-0.90$ & 0.83 & $0.77-0.90$ & 0.78 & $0.72-0.84$ \\
\hline \multicolumn{11}{|l|}{ Age at diagnosis group } \\
\hline $20-49$ & 801 & 621 & 1.00 & - & 1.00 & - & 1.00 & - & 1.00 & - \\
\hline $50-59$ & 1173 & 996 & 1.46 & $1.32-1.62$ & 1.45 & $1.31-1.60$ & 1.44 & $1.30-1.60$ & 1.41 & $1.28-1.56$ \\
\hline $60-69$ & 1270 & 1115 & 1.93 & $1.75-2.13$ & 1.91 & $1.73-2.11$ & 1.91 & $1.72-2.11$ & 1.86 & $1.68-2.06$ \\
\hline $70-$ & 1111 & 1047 & 3.18 & $2.88-3.53$ & 3.12 & $2.81-3.46$ & 3.13 & $2.82-3.48$ & 2.88 & $2.59-3.20$ \\
\hline \multicolumn{11}{|l|}{ Sex } \\
\hline Male & 2607 & 2257 & 1.00 & - & 1.00 & - & 1.00 & - & 1.00 & - \\
\hline Female & 1748 & 1522 & 1.02 & $0.95-1.08$ & 1.00 & $0.93-1.07$ & 1.00 & $0.94-1.07$ & 0.99 & $0.92-1.05$ \\
\hline \multicolumn{11}{|l|}{ Race/Ethnicity } \\
\hline White & 3274 & 2902 & & & 1.00 & - & 1.00 & - & 1.00 & - \\
\hline Black & 269 & 232 & & & 1.05 & $0.92-1.20$ & 1.04 & $0.91-1.19$ & 1 & $0.87-1.14$ \\
\hline Hispanic & 715 & 577 & & & 0.91 & $0.83-1.00$ & 0.89 & $0.82-0.98$ & 0.86 & $0.79-0.94$ \\
\hline Others & 97 & 68 & & & 0.74 & $0.58-0.94$ & 0.73 & $0.57-0.93$ & 0.68 & $0.54-0.87$ \\
\hline \multicolumn{11}{|l|}{ Marital status } \\
\hline Single & 609 & 494 & & & 1.00 & - & 1.00 & - & 1.00 & - \\
\hline Married & 3022 & 2639 & & & 0.97 & $0.88-1.07$ & 0.98 & $0.89-1.08$ & 1.03 & $0.94-1.14$ \\
\hline DWS & 724 & 646 & & & 1.10 & $0.98-1.25$ & 1.12 & $0.99-1.26$ & 1.16 & $1.03-1.31$ \\
\hline \multicolumn{11}{|l|}{ Tumor site } \\
\hline Supratentorial & 3423 & 2961 & & & & & 1.00 & - & 1.00 & - \\
\hline Infratentorial/NOS & 932 & 818 & & & & & 1.25 & $1.16-1.35$ & 1.15 & $1.06-1.24$ \\
\hline \multicolumn{11}{|l|}{ Surgery } \\
\hline No surgery & 753 & 686 & & & & & & & 1.00 & - \\
\hline Local excision/biopsy & 877 & 782 & & & & & & & 0.65 & $0.59-0.73$ \\
\hline Partial resection & 1164 & 1005 & & & & & & & 0.73 & $0.66-0.80$ \\
\hline GTR & 1561 & 1306 & & & & & & & 0.56 & $0.51-0.61$ \\
\hline \multicolumn{11}{|l|}{ Radiation } \\
\hline Untreated & 1332 & 1157 & & & & & & & 1.00 & - \\
\hline Treated & 3023 & 2622 & & & & & & & 0.71 & $0.66-0.77$ \\
\hline
\end{tabular}

Abbreviation: DWS, divorced or widowed or separated; NOS, not otherwise specified; GTR, gross total resection; HR, hazard ratio; $95 \% \mathrm{CI}$, $95 \%$ confidence interval.

a: Model 1: Adjusted age at diagnosis, sex, race/ethnicity and marital status.

b: Model 2: Adjusted age at diagnosis, sex, race/ethnicity, marital status and tumor site.

c: Model 3: Adjusted age at diagnosis, sex, race/ethnicity, marital status, tumor site, surgery and radiation.

DNA replication, the depletion of $M G M T$ repair enzyme activity [37], [38] or methylation of the $M G M T$ promoter [5] after receiving the RT-TMZ. Two studies [39], [40] indicated that BEV has glucocorticoid-like and steroidsparing effects which was nicknamed as "super-steroid" and has resulted in diminished glucocorticoids dosage or need, reduction in edema or possibly in tumor size. However, it is unlikely that steroid-like effect alone can produce such significant durable survival benefit observed in all three cohorts for the follow-up duration of 4 years since FDA approval in 2009. We believe BEV alone or in combination with TMZ or other chemo-radiation therapies have a therapeutic effect on extending survival of GBM patients.

Median OS and 1-year or 2-year survival rate in our study were lower than those reported from previous clinical trials in GBM patients including RT-TMZ [11], Dose-Dense (DD) TMZ [41], TMZ+TTFields 
Table 5: Risky of death among GBM patients in relation to calendar period of diagnosis in the combined dataset $(\mathrm{N}=\mathbf{2 8 9 3 3 )}$

\begin{tabular}{|c|c|c|c|c|c|c|c|c|c|c|c|c|}
\hline \multirow{2}{*}{ Predictors } & \multirow{2}{*}{$\frac{\text { Cases }}{\mathrm{N}}$} & \multirow{2}{*}{$\begin{array}{c}\text { Death } \\
\mathbf{N}\end{array}$} & \multicolumn{2}{|c|}{ Age-sex adjusted } & \multicolumn{2}{|c|}{ Model 1 ${ }^{\mathrm{a}}$} & \multicolumn{2}{|c|}{ Model $2^{\mathrm{b}}$} & \multicolumn{2}{|c|}{ Model $3^{\mathrm{c}}$} & \multicolumn{2}{|c|}{ Model $4^{\mathrm{d}}$} \\
\hline & & & HR & $95 \% \mathrm{CI}$ & HR & $95 \% \mathrm{CI}$ & HR & $95 \% \mathrm{CI}$ & HR & $95 \% \mathrm{CI}$ & HR & $95 \% \mathrm{CI}$ \\
\hline \multicolumn{13}{|l|}{ Calendar period of diagnosis } \\
\hline Jan 2000-Feb 2005 (P1) & 9526 & 9278 & 1.00 & - & 1.00 & - & 1.00 & - & 1.00 & - & 1.00 & - \\
\hline Mar 2005-Apr 2009 (P2) & 8706 & 8264 & 0.82 & $0.79-0.84$ & 0.82 & $0.79-0.84$ & 0.82 & $0.80-0.85$ & 0.82 & $0.80-0.85$ & 0.82 & $0.80-0.85$ \\
\hline May 2009-Dec 2013 (P3) & 10701 & 7601 & 0.75 & $0.73-0.77$ & 0.75 & $0.73-0.78$ & 0.76 & $0.73-0.78$ & 0.76 & $0.73-0.78$ & 0.76 & $0.73-0.78$ \\
\hline \multicolumn{13}{|l|}{ Age at diagnosis group } \\
\hline $20-49$ & 5180 & 4022 & 1.00 & - & 1.00 & - & & & & & & \\
\hline $50-59$ & 7457 & 6317 & 1.50 & $1.44-1.56$ & 1.50 & $1.44-1.56$ & 1.49 & $1.44-1.56$ & 1.48 & $1.43-1.55$ & 1.49 & $1.43-1.55$ \\
\hline $60-69$ & 8310 & 7301 & 2.01 & $1.93-2.09$ & 2.01 & $1.94-2.10$ & 2.02 & $1.94-2.10$ & 1.98 & $1.90-2.06$ & 1.98 & $1.90-2.06$ \\
\hline $70-$ & 7986 & 7503 & 3.40 & $3.26-3.53$ & 3.36 & $3.22-3.50$ & 3.36 & $3.23-3.50$ & 3.09 & $2.96-3.22$ & 3.09 & $2.96-3.22$ \\
\hline \multicolumn{13}{|l|}{ Sex } \\
\hline Male & 17039 & 14788 & 1.00 & - & 1.00 & - & & & & & & \\
\hline Female & 11894 & 10355 & 0.97 & $0.95-1.00$ & 0.95 & $0.92-0.97$ & 0.95 & $0.92-0.97$ & 0.95 & $0.93-0.97$ & 0.95 & $0.93-0.97$ \\
\hline \multicolumn{13}{|l|}{ Race/Ethnicity } \\
\hline White & 23042 & 20301 & & & 1.00 & - & & & & & & \\
\hline Black & 1610 & 1366 & & & 1.06 & $1.01-1.12$ & 1.06 & $1.00-1.12$ & 1.02 & $0.96-1.07$ & 1.02 & $0.96-1.08$ \\
\hline Hispanic & 3059 & 2515 & & & 0.96 & $0.92-1.00$ & 0.95 & $0.92-0.99$ & 0.91 & $0.87-0.95$ & 0.92 & $0.88-0.96$ \\
\hline Others & 1222 & 961 & & & 0.82 & $0.77-0.88$ & 0.81 & $0.76-0.87$ & 0.79 & $0.74-0.84$ & 0.79 & $0.74-0.84$ \\
\hline \multicolumn{13}{|l|}{ Marital status } \\
\hline Single & 3868 & 3161 & & & & & & & & & & \\
\hline Married & 19693 & 17107 & & & 0.91 & $0.87-0.94$ & 0.91 & $0.87-0.94$ & 0.96 & $0.92-1.00$ & 0.96 & $0.92-1.00$ \\
\hline DWS & 5372 & 4875 & & & 1.10 & $1.05-1.15$ & 1.10 & $1.05-1.15$ & 1.13 & $1.08-1.18$ & 1.13 & $1.08-1.18$ \\
\hline \multicolumn{13}{|l|}{ Tumor site } \\
\hline Supratentorial & 22428 & 19341 & & & & & & & & & & \\
\hline Infratentorial/NOS & 6505 & 5802 & & & & & 1.24 & $1.21-1.28$ & 1.14 & $1.11-1.18$ & 1.14 & $1.11-1.18$ \\
\hline \multicolumn{13}{|l|}{ Surgery } \\
\hline No surgery & 5349 & 5018 & & & & & & & & & & \\
\hline Local excision/biopsy & 5749 & 5077 & & & & & & & 0.61 & $0.59-0.64$ & 0.61 & $0.59-0.64$ \\
\hline Partial resection & 8237 & 7116 & & & & & & & 0.66 & $0.64-0.69$ & 0.66 & $0.64-0.69$ \\
\hline $\begin{array}{l}\text { Gross subtotal resection } \\
\text { (GTR) }\end{array}$ & 9598 & 7932 & & & & & & & 0.50 & $0.48-0.52$ & 0.50 & $0.48-0.52$ \\
\hline \multicolumn{13}{|l|}{ Radiation } \\
\hline Untreated & 5981 & 5543 & & & & & & & & & & \\
\hline Treated & 22952 & 19600 & & & & & & & 0.55 & $0.53-0.56$ & 0.54 & $0.52-0.56$ \\
\hline \multicolumn{13}{|l|}{ Cancer Registries } \\
\hline TCR & 4355 & 3779 & & & & & & & & & & \\
\hline SEER & 24578 & 21364 & & & & & & & & & 1.07 & $1.03-1.11$ \\
\hline
\end{tabular}

Abbreviation: DWS, divorced or widowed or separated; NOS, not otherwise specified; GTR, gross total resection; HR, hazard ratio; $95 \% \mathrm{CI}, 95 \%$ confidence interval. a: Model 1: Adjusted age at diagnosis, sex, race/ethnicity and marital status.

b: Model 2: Adjusted age at diagnosis, sex, race/ethnicity, marital status and tumor site.

c: Model 3: Adjusted age at diagnosis, sex, race/ethnicity, marital status, tumor site, surgery and radiation.

d: Model 4: Adjusted age at diagnosis, sex, race/ethnicity, marital status, tumor site, surgery, radiation and cancer registries.

(Novo-TTF device) [42], BEV [27], BEV+RT-TMZ [26] or Rindopepimut/GM-CSF (no results available) (Supplementary Table 1). Considering the TMZ effect on GBM survival, the median OS was 10 months within P2 (post-RT-TMZ and pre-BEV) for all three datasets
(SEER, TCR and the combined dataset). This was a 30$40 \%$ reduction comparing the median OSs reported in the EORTC-NCIC trial (EORTC 26981/22981: NCIC CE.3 intergroup trial, 14.6 months with RT-TMZ) [11], RTOG 0525 trial (16.6 months in control arm with SOC) [41] and 
EF-14 trial (15.6 months in control arm with SOC) [42]. Two-year survival rate during P2 (SEER: 18.8\%, TCR: $20.4 \%$ and the combined dataset: $19.1 \%$ ) was lower than those reported in RCTs $(26.5 \%$ in EORTC-NCIC trial [11], $34.2 \%$ in RTOG 0525 trial [41] and 29\% in EF-14 trial [42]) (Supplementary Table 1).

A similar pattern was observed for the impact of $\mathrm{BEV}$ on GBM survival given our result of median OS during P3 (11.0 months) was approximate 30-35\% lower than that of RTOG 0825 trial (15.7 months in BEV arm) [27] and AVAglio (BO21990) trial (16.8 months with BEV+RT-TMZ) [26]. In the present study, 1-year survival rate was improved significantly from P2 to P3 in SEER and the combined dataset, but significant improvement in 2-year survival rate from P2 to P3 was not detected. These findings were in accord with Chinot et al study a. SEER
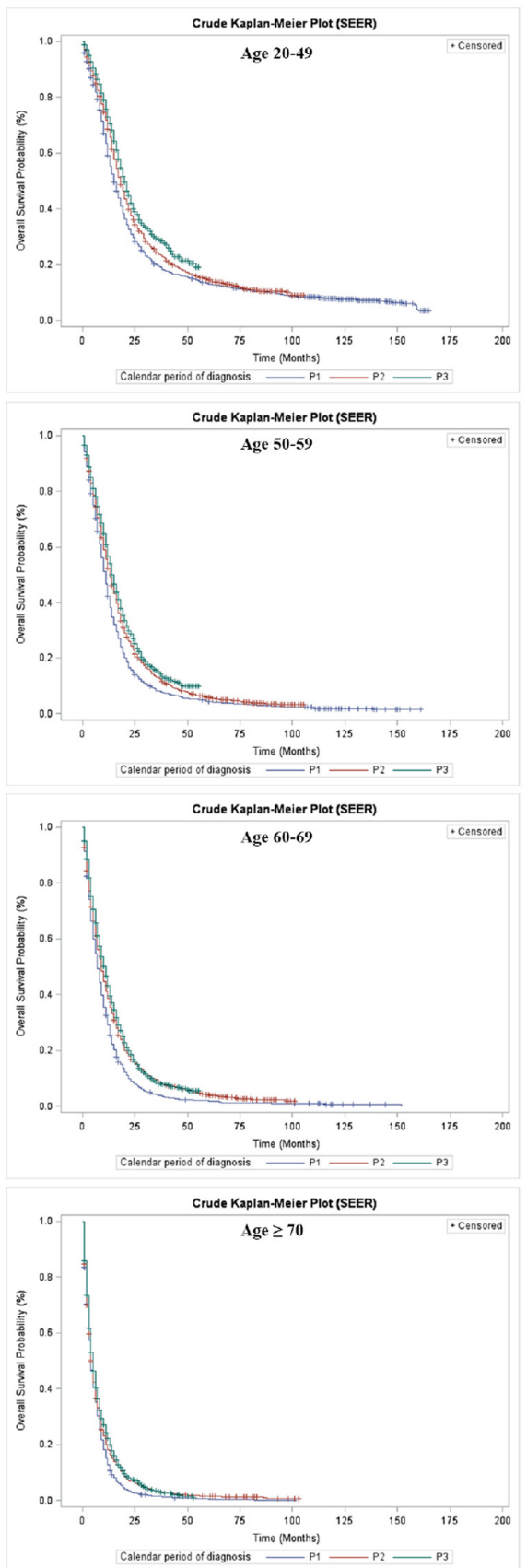

b. TCR

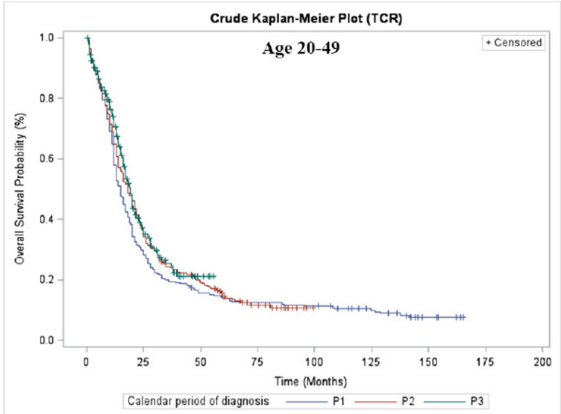

Crude Kaplan-Meier Plot (TCR)

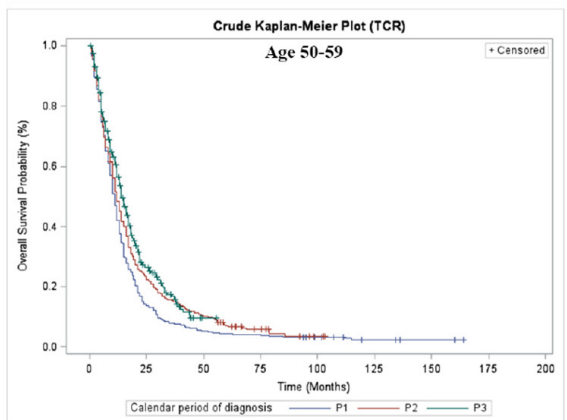

Crude Kaplan-Meier Plot (TCR)
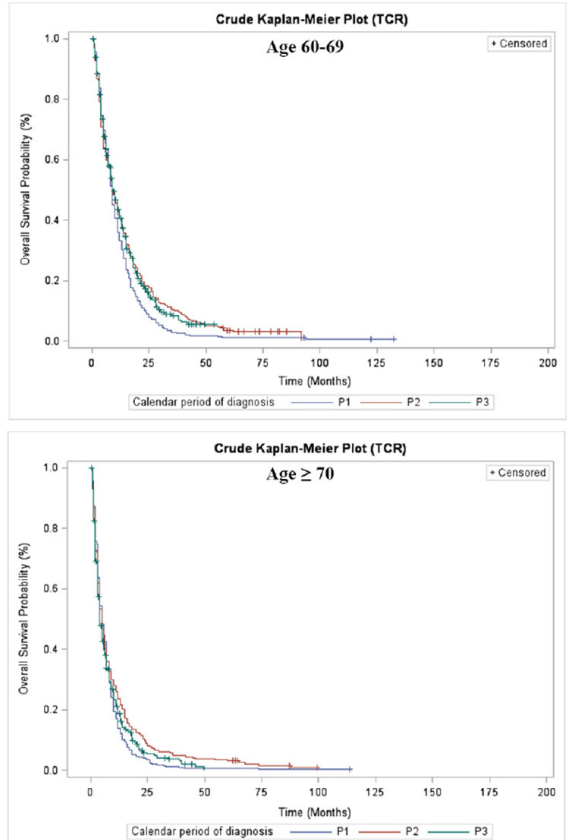

\section{c. Combined dataset}
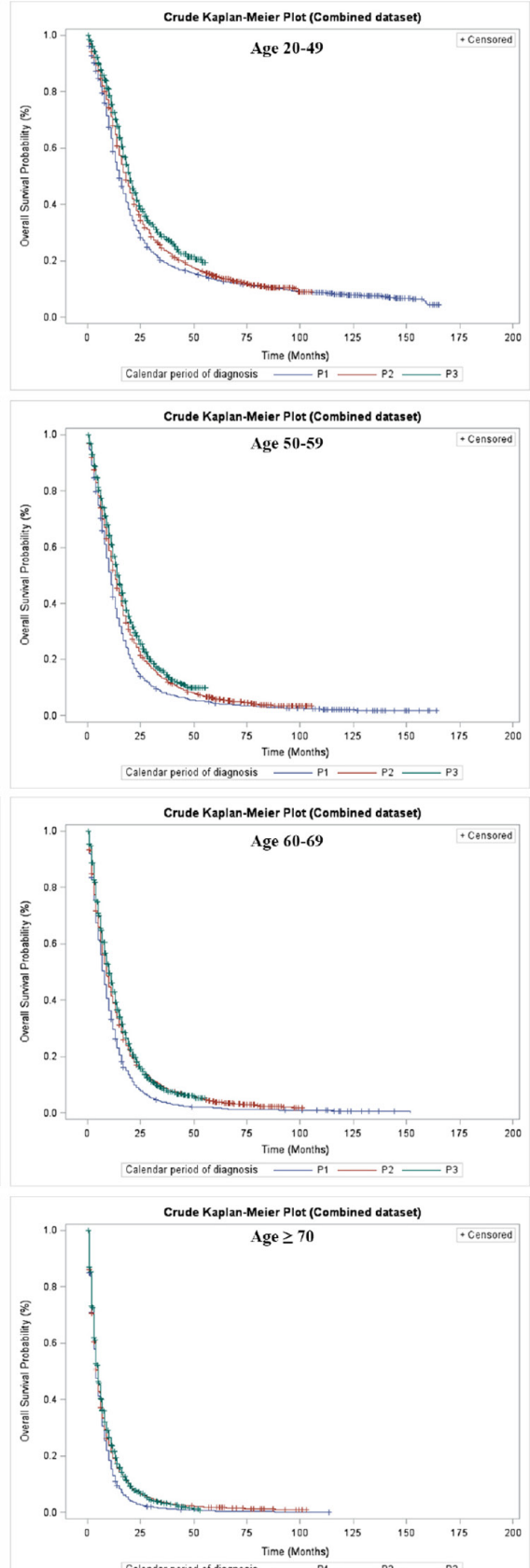

Figure 2: Overall survival of GBM patients by calendar period of diagnosis and age group at diagnosis in SEER, TCR and the combined dataset, Kaplan-Meier survival estimates. (a) Crude overall survival stratified by age group at diagnosis in SEER; (b) Crude overall survival stratified by age group at diagnosis in TCR; (c) Crude overall survival stratified by age group at diagnosis in the combined dataset. 
[26] (1-year survival rate was significantly improved in BEV+RT-TMZ arm, $P=0.049$, but no significance found in 2-year survival rate between BEV+RT-TMZ arm and Placebo+RT-TMZ arm, $P=0.240$ ). The apparent difference in survival between our study and prior RCTs might be explained by selection bias favoring RCTs. For example, all clinical trials patients were selected with good performance status, younger age ranges, adequate hematologic, cardiovascular, renal, and hepatic function without significant comorbidity [11], [26], [27], [41], [42] (Supplementary Table 1).

By contrast, the results in our study were comparable to the median OS and survival rate presented in the population-based studies by using SEER, VHA and NPD (Norwegian Prescription Database) linked CRN (Cancer Registry of Norway), even though most studies a. SEER
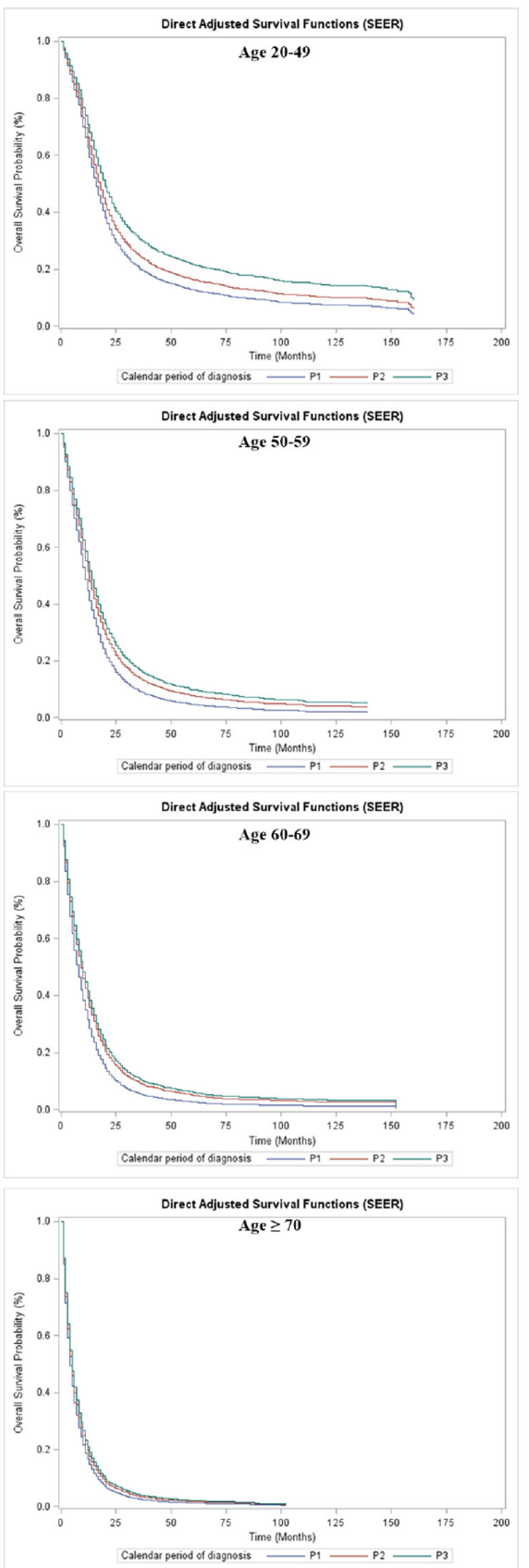

b. TCR

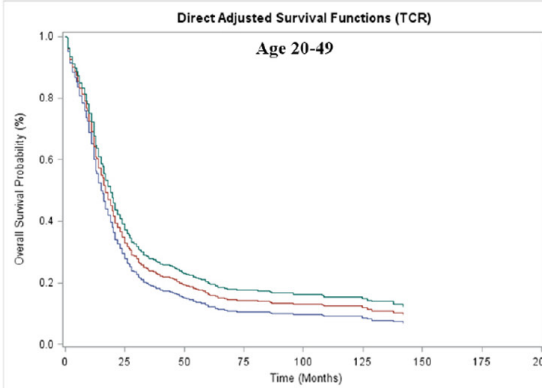
Calendar period of diagnosis
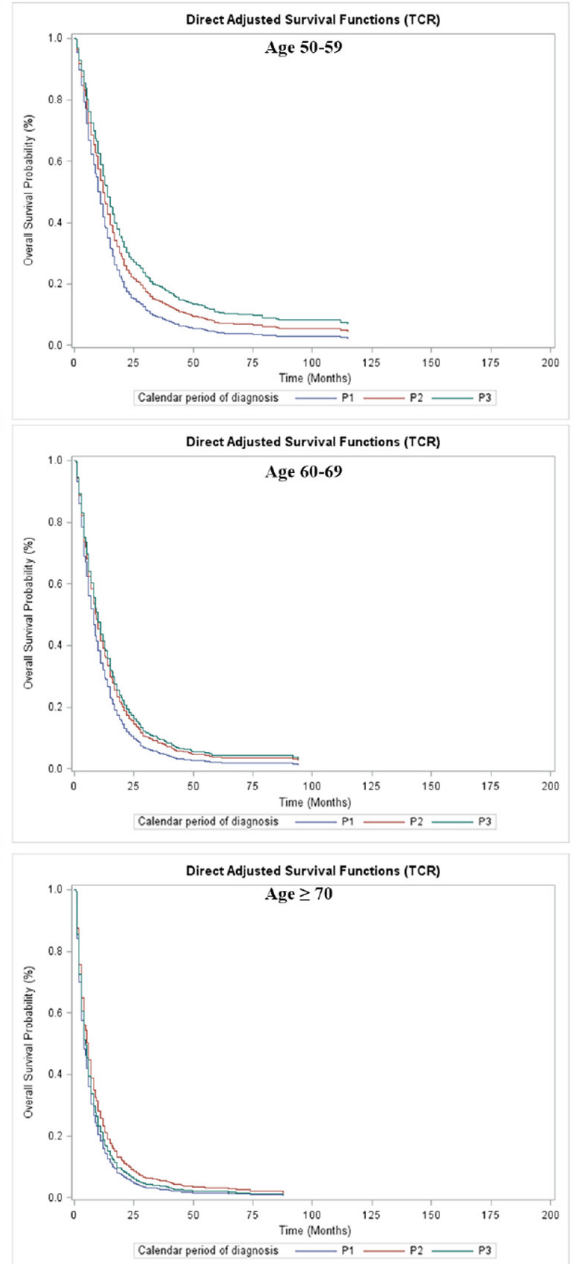

c. Combined dataset
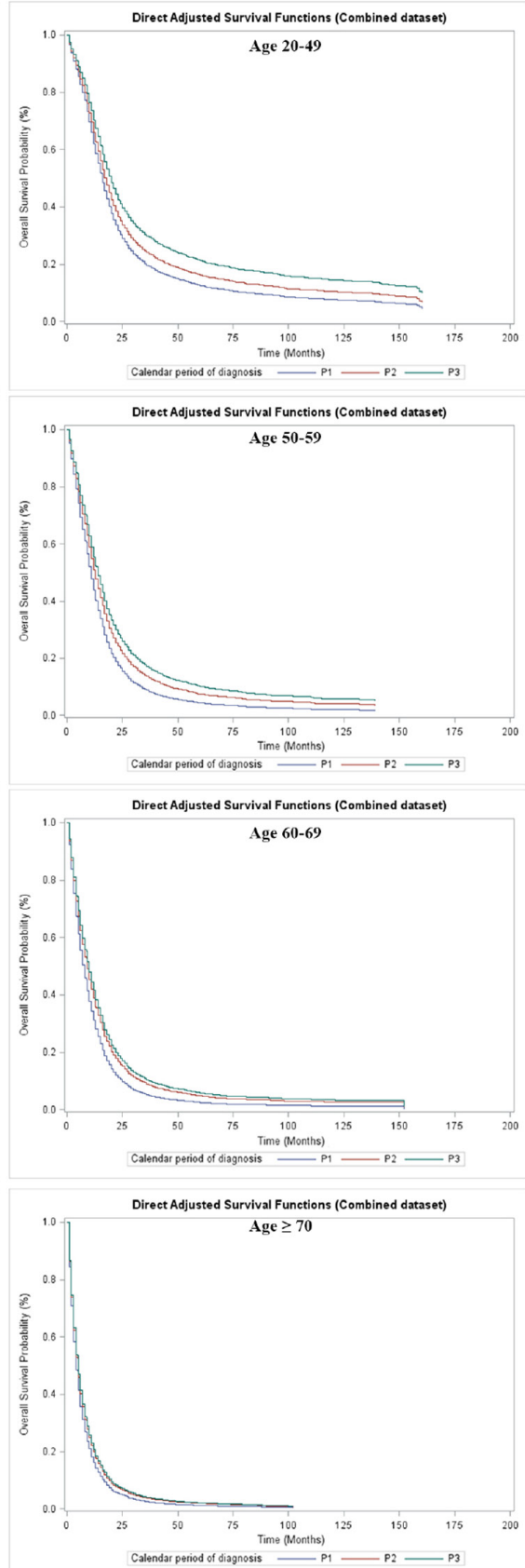

Figure 3: Overall survival of GBM patients by calendar period of diagnosis and age group at diagnosis in SEER, TCR and the combined dataset, direct adjusted survival functions. (a) Direct adjusted survival after adjusting covariates stratified by age group at diagnosis in SEER; (b) Direct adjusted survival after adjusting covariates stratified by age group at diagnosis in TCR; (c) Direct adjusted survival after adjusting covariates stratified by age group at diagnosis in the combined dataset. 
Table 6: Risk of death in GBM patients by calendar period of diagnosis and by time-varying covariates*

\begin{tabular}{|c|c|c|c|c|c|c|c|c|c|c|c|c|c|c|c|c|c|c|}
\hline \multirow{3}{*}{ Time-varying covariates } & \multicolumn{6}{|c|}{ SEER } & \multicolumn{6}{|c|}{ TCR } & \multicolumn{6}{|c|}{ The combined dataset } \\
\hline & \multicolumn{2}{|c|}{ P1 } & \multicolumn{2}{|r|}{ P2 } & \multicolumn{2}{|r|}{ P3 } & \multicolumn{2}{|c|}{ P1 } & \multicolumn{2}{|r|}{ P2 } & \multicolumn{2}{|r|}{ P3 } & \multicolumn{2}{|c|}{ P1 } & \multicolumn{2}{|r|}{$\mathbf{P 2}$} & \multicolumn{2}{|r|}{ P3 } \\
\hline & HR & $95 \% \mathrm{CI}$ & HR & $95 \% \mathrm{CI}$ & HR & $95 \% \mathrm{CI}$ & HR & $95 \% \mathrm{CI}$ & HR & $95 \%$ CI & HR & $95 \%$ CI & HR & $95 \% \mathrm{CI}$ & HR & $95 \%$ CI & HR & $95 \%$ CI \\
\hline \multicolumn{19}{|l|}{ Age group at diagnosis } \\
\hline $20-49$ & 1.00 & - & 0.87 & $0.81-0.94$ & 0.73 & $0.67-0.80$ & 1.00 & - & 0.86 & $0.71-1.04$ & 0.76 & $0.61-0.94$ & 1.00 & - & 0.87 & $0.81-0.94$ & 0.73 & $0.68-0.80$ \\
\hline $50-59$ & 1.00 & - & 0.82 & $0.77-0.87$ & 0.73 & $0.68-0.78$ & 1.00 & - & 0.80 & $0.69-0.93$ & 0.68 & $0.58-0.79$ & 1.00 & - & 0.81 & $0.76-0.85$ & 0.71 & $0.66-0.75$ \\
\hline $60-69$ & 1.00 & - & 0.80 & $0.75-0.85$ & 0.74 & $0.70-0.79$ & 1.00 & - & 0.82 & $0.70-0.95$ & 0.77 & $0.66-0.89$ & 1.00 & - & 0.80 & $0.75-0.84$ & 0.74 & $0.70-0.78$ \\
\hline $70-$ & 1.00 & - & 0.89 & $0.84-0.95$ & 0.85 & $0.80-0.90$ & 1.00 & - & 0.78 & $0.67-0.91$ & 0.91 & $0.78-1.06$ & 1.00 & - & 0.87 & $0.82-0.92$ & 0.85 & $0.80-0.89$ \\
\hline \multicolumn{19}{|l|}{ Tumor site } \\
\hline Supratentorial & 1.00 & - & 0.83 & $0.80-0.86$ & 0.77 & $0.74-0.80$ & 1.00 & - & 0.76 & $0.70-0.83$ & 0.75 & $0.68-0.82$ & 1.00 & - & 0.81 & $0.79-0.84$ & 0.75 & $0.73-0.78$ \\
\hline Infratentorial/NOS & 1.00 & - & 0.84 & $0.78-0.90$ & 0.76 & $0.71-0.81$ & 1.00 & - & 0.78 & $0.31-1.95$ & 0.74 & $0.30-1.81$ & 1.00 & - & 0.78 & $0.57-1.06$ & 0.76 & $0.55-1.04$ \\
\hline \multicolumn{19}{|l|}{ Surgery } \\
\hline No surgery & 1.00 & - & 0.89 & $0.83-0.95$ & 0.84 & $0.78-0.91$ & 1.00 & - & 0.90 & $0.74-1.08$ & 0.95 & $0.79-1.15$ & 1.00 & - & 0.89 & $0.84-0.95$ & 0.83 & $0.77-0.88$ \\
\hline Local excision/biopsy & 1.00 & - & 0.90 & $0.83-0.97$ & 0.92 & $0.86-0.99$ & 1.00 & - & 0.77 & $0.64-0.92$ & 0.72 & $0.60-0.86$ & 1.00 & - & 0.85 & $0.79-0.91$ & 0.83 & $0.78-0.89$ \\
\hline Partial resection & 1.00 & - & 0.79 & $0.74-0.84$ & 0.74 & $0.69-0.78$ & 1.00 & - & 0.80 & $0.68-0.93$ & 0.70 & $0.60-0.82$ & 1.00 & - & 0.77 & $0.73-0.82$ & 0.70 & $0.66-0.74$ \\
\hline GTR & 1.00 & - & 0.89 & $0.84-0.94$ & 0.80 & $0.75-0.85$ & 1.00 & - & 0.77 & $0.68-0.88$ & 0.78 & $0.68-0.89$ & 1.00 & - & 0.82 & $0.78-0.86$ & 0.73 & $0.69-0.77$ \\
\hline \multicolumn{19}{|l|}{ Radiation } \\
\hline Untreated & 1.00 & - & 0.97 & $0.90-1.04$ & 0.93 & $0.86-1.00$ & 1.00 & - & 0.85 & $0.72-1.00$ & 0.76 & $0.65-0.88$ & 1.00 & - & 0.96 & $0.90-1.02$ & 0.90 & $0.84-0.96$ \\
\hline Treated & 1.00 & - & 0.79 & $0.76-0.82$ & 0.72 & $0.69-0.75$ & 1.00 & - & 0.78 & $0.71-0.85$ & 0.81 & $0.73-0.89$ & 1.00 & - & 0.79 & $0.77-0.82$ & 0.73 & $0.71-0.76$ \\
\hline
\end{tabular}

applied different classification of time periods [21], [23], [24], [25], [28], [29], [31]. The majority of studies on TMZ set 2005 as the cut-off between pre-TMZ and postTMZ eras based on SEER [21], [24] and their results were consistent with our findings within P1 and P2 periods (Supplementary Table 1). Two other studies were based on the VHA database in the U.S. and NPD linked CRN in Norway, respectively, which were independent cohorts from SEER. These studies confirmed and substantiated the beneficial effect of TMZ on GBM survival after the introduction of TMZ concurrent with radiation and adjuvant TMZ. They reported similar median OS and survival rate to our findings.

Two other studies examined the potential survival benefit after the administration of BEV for GBM treatment in "real-world" settings. The conclusion in our study was in agreement with the findings reported by Johnson et al [28]. But they ascertained the time window based on three years of death records and demonstrated that the median OS for the patients deceased in 2006, 2008 and 2009 was 8,7 and 9 months, respectively, whereas no 1-year or 2-year survival rates were presented and all analyses were performed by Mann-Whitney U tests or a log-rank test. Wachtel et al [29] reported 1-year survival rate of the time periods as 31.8\% (Jan 2000-Jun 2003), 37.3\% (Jul 2003-Mar 2005), 41.0\% (Apr 2005-Oct 2007) and 43.0\% (Nov 2007-Dec 2009), which was in consonance with the survival rates reported in our study. However, Wachtel et al defined BEV-TMZ era as "November 2007-December
2009" based on Vredenburgh et al study, a phase II trial result for BEV, which was published in October 2007 [43]. Further, they had no access to the sufficient study subjects who were diagnosed GBM after FDA approval of BEV since their time period of GBM diagnosis was Jan 2000 - Dec 2009. Therefore, they could not provide adequate evidence to prove the prolonged survival benefit after BEV FDA approval (Supplementary Table 1).

The strengths of the present study include: First, we addressed the research question by using two independent population-based datasets with larger sample sizes, longer follow-up periods comparing to previously reported studies [28], [29] and applicable adjustment of demographical and clinical covariates. Second, our paper is the first to explore the association between calendar period of GBM diagnosis and OS in TCR, which is an independent collection of GBM patients from SEER but using a similar standard method of data collection and management to SEER. Third, we also compared survival functions between SEER and TCR within each grouped calendar period and across all periods (including multicomparison among $\mathrm{P} 1, \mathrm{P} 2$ and $\mathrm{P} 3$ ), and re-ran all the analyses based on the combined dataset and TCR with extended follow-up, which served as validation analyses and confirmed our initial observations. Fourth, in Dubrow et al study, the proportion of TMZ usage in the adjuvant chemotherapy increased from $28 \%(2001-2004)$ to $71 \%$ (2005-2008), and the median time to initiate TMZ therapy reduced to 1.0 months in 2005-2008 (lowest 
across all three time periods), which indicated that there is an speedy process of administration of TMZ after FDA approval and patients could obtain TMZ with minimal delay. Arvold et al [44] defined the TMZ era as June 1, 2005 - December 31, 2009, in SEER-Medicare database because they believed TMZ could be widely available in the US after FDA approval. In this regard, we believe FDA approval date can represent the start date of insurance coverage and physician's prescriptions with minimal delays. This is an appropriate proxy to the time-point that majority of qualified GBM patients began to receive TMZ and $\mathrm{BEV}$, respectively. Although there is a delay during implementation of insurance coverage, the interval of delay is very short in this population since there are very limited options of therapies for GBM and the prognosis is extremely poor. This method of categorization could avoid uncertain transition periods and facilitate interpretation. Fifth, we performed stratification analysis, Cox proportional hazards model and direct adjusted survival curves by taking the potential time-varying covariates into account.

There are limitations of the current study: First, the present study was based on a retrospective cohort study, which means the difference in OS among the calendar period of diagnosis could be influenced by confounding factors. To limit the effects from confounders, we have adjusted varied combinations of covariates during the model selection and still achieved consistent results. Second, both SEER and TCR do not offer detailed clinical data, such as performance status, chemotherapy drugs received, numbers of craniotomies with or without Gliadel wafers carried out, salvage radiation or stereotactic radiosurgeries performed, molecular profiles (MGMT [41], $I D H 1 / 2)$ results, as well as direct causes of death, which may influence our ascertainment of OS. Third, other factors may contribute OS variations that are not available in SEER or TCR, including socioeconomic status, access to health insurance, complications or adverse events related to TMZ or BEV. The prior RCTs indicated that the usage of BEV would be associated with an elevated risk of side effects, such as hypertension, thromboembolic events, intestinal perforation or intracranial hemorrhage [26], [27]. Therefore, further studies including the above-mentioned aspects would be necessary to confirm the beneficial effect of TMZ and BEV on OS among GBM patients.

\section{CONCLUSIONS}

Based on a population-based, retrospective study of two independent datasets, SEER and TCR as well as the pooled database from both datasets, we demonstrated that there was a significantly improved OS across the calendar period of GBM diagnosis from January 2000 to December 2013. In multivariate models, the survival benefit over calendar period remained unchanged after stratification. Although we cannot provide a direct causal relationship between concurrent TMZ with radiation, adjuvant TMZ for newly diagnosed GBM followed by BEV for recurrent GBM and successive increased survival in the thirteen years period based on a retrospective population-based analysis, the improved OS was likely resulted from the administrations of TMZ with radiation and adjuvant TMZ and then BEV after FDA approval, respectively.

\section{MATERIALS AND METHODS}

\section{Study settings and populations}

The latest database of the SEER Program (released on April 15, 2016) included cancer incidence and survival data across 18 population-based cancer registries in the United States (Connecticut, New Jersey, Detroit, Iowa, Kentucky, Louisiana, Atlanta, rural Georgia, greater Georgia, Hawaii, New Mexico, Seattle-Puget Sound, Utah, San Francisco-Oakland, San Jose-Monterey, Los Angeles, greater California, Alaska), covering approximately 30\% of the U.S. population from January 2000 to December 2013. We requested access to the data and obtained permission from the National Cancer Institute (NCI), Division of Cancer Control and Population Sciences, Surveillance Research Program. The details of description, recruitment methodology, quality of control and followup protocols about SEER program were described elsewhere [45]. The TCR Limited-Use database for cancer diagnosed from 1995 to 2013, which is not included in the SEER database, has been developed since 1979 by the Texas Department of State Health Services, including demographics, clinical characteristics, and survival information. The variable settings of core data in TCR are similar to those collected in the SEER database and meet the high-quality data standards by National Program of Central Cancer Registries (NPCR), and Centers for Disease Control and Prevention [46].

Glioblastoma Multiforme (GBM) was defined by International Classification of Disease for Oncology, third edition (ICD-O-3) coded as 9440, 9441, or 9442 [21], [22], [24], [47], with topography codes C710-C719 and malignant brain neoplasm (behavior code was 3 ). Subjects were excluded due to the following criteria: age at diagnosis less than 20 years old; not primary tumors; patients diagnosed only from autopsy or from death certificate; not microscopically-confirmed; unknown race, marital status; the extent of surgery; or radiation therapy status and lack of survival data [21], [22], [23], [48], [49]. The final analytic dataset was limited to 24,578 and 4,355 GBM patients in SEER and TCR, respectively, and we also combined these two datasets for validation analysis. Since TCR offers longer follow-up period until May 2015, we did sub-analysis of P3 including the extended followup period and the results are reported in supplemental tables. 


\section{Predictors, covariates, and outcome}

Since detailed chemotherapy regimens were not available in SEER and TCR, we separated the study cohorts into three groups based on the FDA approval dates of TMZ as concurrent use with RT and then BEV, respectively: January 2000-February 2005 (pre-RT-TMZ and pre-BEV, P1), March 2005-April 2009 (post-RT-TMZ and pre-BEV, P2), and May 2009-December 2013 (postRT-TMZ and post-BEV, P3). Covariates included age at diagnosis (20-49, 50-59, 60-69, $\geq 70$ years), sex, race/ ethnicity (White, Black, Hispanic and Others) and marital status (single, married, separated, divorced, or widowed). Tumor location (topography codes C710-C719) was also considered in this analysis [50], [51]. The relevant treatment variables included the extent of surgery (no surgery, local excision/biopsy, partial resection and gross total resection) [24], [50], [52] and radiation status (untreated and treated) [22], [24]. Since the cutoff of the last follow-up varied between SEER (December 31, 2013) and TCR (553 patients were followed up to May 2015), we set our cutoff date as December 31, 2013 in both SEER and TCR, which means we censored those who were still alive by December 31, 2013 in TCR. The primary endpoint was OS, which was defined as the subsequent months from diagnosis to the date of death due to any cause or the date of last follow-up or December 31, 2013. We also performed sub-analysis in TCR with extended follow-up up to May 2015, which could provide data for a longer term follow-up of OS associated with the usage of $\mathrm{BEV}$ in GBM patients.

\section{Ethics statement}

Since SEER and TCR Limited-Use database are composed of existing and de-identified data, there is no individual patient-identifiable information. The study was approved by the Committee for the Protection of Human Subjects Committee from University of Texas Health Science Center at Houston (UTHealth), McGovern Medical School, Houston, TX.

\section{Statistical analysis}

Descriptive statistics were used to depict and compare the cohort characteristics by calendar period of diagnosis using Mann-Whitney U test or Pearson's $\chi^{2}$ test. OS was assessed by applying Kaplan-Meier method and the difference between survival curves was tested by the two-sided log-rank test. Median OS, 1-year or 2-year survival rate (\%) were calculated in patients who were observed for at least 1 or 2 years, and the difference in 1-year or 2-year survival rate across calendar period of diagnosis was tested by two-sided Chi-square test with Schouten correction. Univariate and multivariate analysis were applied by Cox proportional hazards model. In multivariate analysis, calendar period of diagnosis was included into models by adjusting the different sets of covariates: Model 1, Model 2 and Model 3 for SEER and TCR; Model 1, Model 2, Model 3 and Model 4 for the combined dataset (See details in Table 3, Table 4 and Table 5). The models were conducted to estimate HRs (95\% CI) by adjusting for the potential confounding factors. After testing the proportional hazard assumption, the interactions between time and age at diagnosis, tumor site, surgery and radiation on OS were significant. Hence, stratified analysis Cox model was performed by involving the time-varying effect of age at diagnosis, tumor site, surgery and radiation. We obtained direct adjusted survival curves based on Model 3 for SEER, TCR, and Model 4 for the combined dataset, which computed the average of estimated survival curves for each patient, instead of generating adjusted curves by applying means of covariates [53], [54]. All statistical analyses were performed with Stata 12.0 (StataCorp, College Station, TX) and SAS (Version 9.3, SAS Institute, Cary, NC). $P$ values were two-sided and considered statistically significant at $P<0.05$.

\section{ACKNOWLEDGMENTS}

We are very grateful for the assistance and support provided by Ms. Miriam M. Morales-Morris, Dr. Zheyu Liu, and Dr. Joanna S. O'Leary in the preparation of this manuscript and for help offered from representatives from the Texas Cancer Registry.

\section{CONFLICTS OF INTEREST}

The authors declare no conflicts of interest.

\section{FUNDING}

This study is partially supported by the fund from Dr. Marnie Rose Foundation.

\section{REFERENCES}

1. Ostrom QT, Gittleman H, Fulop J, Liu M, Blanda R, Kromer C, Wolinsky Y, Kruchko C, Barnholtz-Sloan JS. CBTRUS Statistical Report: Primary Brain and Central Nervous System Tumors Diagnosed in the United States in 2008-2012. Neuro Oncol. 2015; 17 Suppl 4: iv1-iv62.

2. Lacroix M, Abi-Said D, Fourney DR, Gokaslan ZL, Shi W, DeMonte F, Lang FF, McCutcheon IE, Hassenbusch SJ, Holland E, Hess K, Michael C, Miller D, et al. A multivariate analysis of 416 patients with glioblastoma multiforme: prognosis, extent of resection, and survival. J Neurosurg. 2001; 95: 190-8.

3. Stummer W, Pichlmeier U, Meinel T, Wiestler OD, Zanella F, Reulen HJ, ALA-Glioma Study Group. Fluorescenceguided surgery with 5-aminolevulinic acid for resection 
of malignant glioma: a randomised controlled multicentre phase III trial. Lancet Oncol. 2006; 7: 392-401.

4. Bauchet L, Mathieu-Daudé H, Fabbro-Peray P, Rigau V, Fabbro M, Chinot O, Pallusseau L, Carnin C, Lainé K, Schlama A, Thiebaut A, Patru MC, Bauchet F, et al. Oncological patterns of care and outcome for 952 patients with newly diagnosed glioblastoma in 2004. Neuro Oncol. 2010; 12: 725-35.

5. Hegi ME, Diserens AC, Gorlia T, Hamou MF, de Tribolet N, Weller M, Kros JM, Hainfellner JA, Mason W, Mariani L, Bromberg JEC, Hau P, Mirimanoff RO, et al. MGMT gene silencing and benefit from temozolomide in glioblastoma. N Engl J Med. 2005; 352: 997-1003.

6. Chen Y, Hu F, Zhou Y, Chen W, Shao H, Zhang Y. MGMT Promoter Methylation and Glioblastoma Prognosis: A Systematic Review and Meta-analysis. Arch Med Res. 2013; 44: 281-90.

7. Goodenberger ML, Jenkins RB. Genetics of adult glioma. Cancer Genet. 2012; 205: 613-21.

8. Noushmehr H, Weisenberger DJ, Diefes K, Phillips HS, Pujara K, Berman BP, Pan F, Pelloski CE, Sulman EP, Bhat KP, Verhaak RGW, Hoadley KA, Hayes DN, et al. Identification of a $\mathrm{CpG}$ island methylator phenotype that defines a distinct subgroup of glioma. Cancer Cell. 2010; 17: 510-22.

9. Phillips HS, Kharbanda S, Chen R, Forrest WF, Soriano RH, Wu TD, Misra A, Nigro JM, Colman H, Soroceanu L, Williams PM, Modrusan Z, Feuerstein BG, et al. Molecular subclasses of high-grade glioma predict prognosis, delineate a pattern of disease progression, and resemble stages in neurogenesis. Cancer Cell. 2006; 9: 157-73.

10. Verhaak RGW, Hoadley KA, Purdom E, Wang V, Qi Y, Wilkerson MD, Miller CR, Ding L, Golub T, Mesirov JP, Alexe G, Lawrence M, O'Kelly M, et al. Integrated genomic analysis identifies clinically relevant subtypes of glioblastoma characterized by abnormalities in PDGFRA, IDH1, EGFR, and NF1. Cancer Cell. 2010; 17: 98-110.

11. Stupp R, Mason WP, van den Bent MJ, Weller M, Fisher B, Taphoorn MJB, Belanger K, Brandes AA, Marosi C, Bogdahn U, Curschmann J, Janzer RC, Ludwin SK, et al. Radiotherapy plus concomitant and adjuvant temozolomide for glioblastoma. N Engl J Med. 2005; 352: 987-96.

12. Cohen MH, Johnson JR, Pazdur R. Food and Drug Administration Drug approval summary: temozolomide plus radiation therapy for the treatment of newly diagnosed glioblastoma multiforme. Clin Cancer Res. 2005; 11: 6767-71.

13. Brem H, Piantadosi S, Burger PC, Walker M, Selker R, Vick NA, Black K, Sisti M, Brem S, Mohr G. Placebo-controlled trial of safety and efficacy of intraoperative controlled delivery by biodegradable polymers of chemotherapy for recurrent gliomas. The Polymer-brain Tumor Treatment Group. Lancet. 1995; 345: 1008-12.
14. Yung WK, Albright RE, Olson J, Fredericks R, Fink K, Prados MD, Brada M, Spence A, Hohl RJ, Shapiro W, Glantz M, Greenberg H, Selker RG, et al. A phase II study of temozolomide vs. procarbazine in patients with glioblastoma multiforme at first relapse. Br J Cancer. 2000; 83: 588-93.

15. Keles GE, Lamborn KR, Chang SM, Prados MD, Berger MS. Volume of residual disease as a predictor of outcome in adult patients with recurrent supratentorial glioblastomas multiforme who are undergoing chemotherapy. J Neurosurg. 2004; 100: 41-6.

16. Butowski NA, Sneed PK, Chang SM. Diagnosis and treatment of recurrent high-grade astrocytoma. J Clin Oncol. 2006; 24: 1273-80.

17. Friedman HS, Prados MD, Wen PY, Mikkelsen T, Schiff D, Abrey LE, Yung WKA, Paleologos N, Nicholas MK, Jensen R, Vredenburgh J, Huang J, Zheng M, et al. Bevacizumab alone and in combination with irinotecan in recurrent glioblastoma. J Clin Oncol. 2009; 27: 4733-40.

18. Kreisl TN, Kim L, Moore K, Duic P, Royce C, Stroud I, Garren N, Mackey M, Butman JA, Camphausen K, Park J, Albert PS, Fine HA. Phase II trial of single-agent bevacizumab followed by bevacizumab plus irinotecan at tumor progression in recurrent glioblastoma. J Clin Oncol. 2009; 27: 740-5.

19. Cohen MH, Shen YL, Keegan P, Pazdur R. FDA drug approval summary: bevacizumab (Avastin) as treatment of recurrent glioblastoma multiforme. Oncologist. 2009; 14: 1131-8.

20. Shahar T, Nossek E, Steinberg DM, Rozovski U, Blumenthal DT, Bokstein F, Sitt R, Freedman S, Corn BW, Kanner AA, Ram Z. The impact of enrollment in clinical trials on survival of patients with glioblastoma. J Clin Neurosci. 2012; 19: 1530-4.

21. Darefsky AS, King JT Jr, Dubrow R. Adult glioblastoma multiforme survival in the temozolomide era: A populationbased analysis of Surveillance, Epidemiology, and End Results registries. Cancer. 2011; 118: 2163-72.

22. Koshy M, Villano JL, Dolecek TA, Howard A, Mahmood U, Chmura SJ, Weichselbaum RR, McCarthy BJ. Improved survival time trends for glioblastoma using the SEER 17 population-based registries. J Neurooncol. 2011; 107: 207-12.

23. Lawrence YR, Mishra MV, Werner-Wasik M, Andrews DW, Showalter TN, Glass J, Shen X, Symon Z, Dicker AP. Improving prognosis of glioblastoma in the 21 st century: Who has benefited most? Cancer. 2011; 118: 4228-34.

24. Johnson DR, O'Neill BP. Glioblastoma survival in the United States before and during the temozolomide era. J Neurooncol. 2012; 107: 359-64.

25. Dubrow R, Darefsky AS, Jacobs DI, Park LS, Rose MG, Laurans MSH, King JT. Time trends in glioblastoma multiforme survival: the role of temozolomide. Neuro Oncol. 2013; 15: 1750-61. 
26. Chinot OL, Wick W, Mason W, Henriksson R, Saran F, Nishikawa R, Carpentier AF, Hoang-Xuan K, Kavan P, Cernea D, Brandes AA, Hilton M, Abrey L, et al. Bevacizumab plus radiotherapy-temozolomide for newly diagnosed glioblastoma. N Engl J Med. 2014; 370: 709-22.

27. Gilbert MR, Dignam JJ, Armstrong TS, Wefel JS, Blumenthal DT, Vogelbaum MA, Colman H, Chakravarti A, Pugh S, Won M, Jeraj R, Brown PD, Jaeckle KA, et al. A randomized trial of bevacizumab for newly diagnosed glioblastoma. N Engl J Med. 2014; 370: 699-708.

28. Johnson DR, Leeper HE, Uhm JH. Glioblastoma survival in the United States improved after Food and Drug Administration approval of bevacizumab: a populationbased analysis. Cancer. 2013; 119: 3489-95.

29. Wachtel MS, Yang S. Odds of death after glioblastoma diagnosis in the United States by chemotherapeutic era. Cancer Med. 2014; 3: 660-6.

30. Stupp R, Hegi ME, Mason WP, van den Bent MJ, Taphoorn MJ, Janzer RC, Ludwin SK, Allgeier A, Fisher B, Belanger K, Hau P, Brandes AA, Gijtenbeek J, et al. Effects of radiotherapy with concomitant and adjuvant temozolomide versus radiotherapy alone on survival in glioblastoma in a randomised phase III study: 5-year analysis of the EORTCNCIC trial. Lancet Oncol. 2009; 10: 459-66.

31. Ronning PA, Helseth E, Meling TR, Johannesen TB. A population-based study on the effect of temozolomide in the treatment of glioblastoma multiforme. Neuro Oncol. 2012; 14: 1178-84.

32. Smith JC, Medalia C. U.S. Census Bureau, Current Population Reports, P60-250, Health Insurance Coverage in the United States: 2013, U.S. Government Printing Office, Washington, DC, 2014.

33. Smith JC, Medalia C. U.S. Census Bureau, Current Population Reports, P60-253, Health Insurance Coverage in the United States: 2014, U.S. Government Printing Office, Washington, DC, 2015.

34. Yan H, Parsons DW, Jin G, McLendon R, Rasheed BA, Yuan W, Kos I, Batinic-Haberle I, Jones S, Riggins GJ, Friedman H, Friedman A, Reardon D, et al. IDH1 and IDH2 mutations in gliomas. N Engl J Med. 2009; 360: 765-73.

35. Parsons DW, Jones S, Zhang X, Lin JCH, Leary RJ, Angenendt P, Mankoo P, Carter H, Siu IM, Gallia GL, Olivi A, McLendon R, Rasheed BA, et al. An integrated genomic analysis of human glioblastoma multiforme. Science. 2008; 321: 1807-12.

36. Sandmann T, Bourgon R, Garcia J, Li C, Cloughesy T, Chinot OL, Wick W, Nishikawa R, Mason W, Henriksson R, Saran F, Lai A, Moore N, et al. Patients With Proneural Glioblastoma May Derive Overall Survival Benefit From the Addition of Bevacizumab to First-Line Radiotherapy and Temozolomide: Retrospective Analysis of the AVAglio Trial. J Clin Oncol. 2015; 33: 2735-44.
37. Tolcher AW, Gerson SL, Denis L, Geyer C, Hammond LA, Patnaik A, Goetz AD, Schwartz G, Edwards T, Reyderman L, Statkevich P, Cutler DL, Rowinsky EK. Marked inactivation of O6-alkylguanine-DNA alkyltransferase activity with protracted temozolomide schedules. $\mathrm{Br} \mathrm{J}$ Cancer. 2003; 88: 1004-11.

38. Friedman HS, McLendon RE, Kerby T, Dugan M, Bigner SH, Henry AJ, Ashley DM, Krischer J, Lovell S, Rasheed K, Marchev F, Seman AJ, Cokgor I, et al. DNA mismatch repair and O6-alkylguanine-DNA alkyltransferase analysis and response to Temodal in newly diagnosed malignant glioma. J Clin Oncol. 1998; 16: 3851-7.

39. Vredenburgh JJ, Cloughesy T, Samant M, Prados M, Wen PY, Mikkelsen T, Schiff D, Abrey LE, Yung WKA, Paleologos N, Nicholas MK, Jensen R, Das A, et al. Corticosteroid use in patients with glioblastoma at first or second relapse treated with bevacizumab in the BRAIN study. Oncologist. 2010; 15: 1329-34.

40. Pitter KL, Tamagno I, Alikhanyan K, Hosni-Ahmed A, Pattwell SS, Donnola S, Dai C, Ozawa T, Chang M, Chan TA, Beal K, Bishop AJ, Barker CA, et al. Corticosteroids compromise survival in glioblastoma. Brain. 2016; 139: $1458-71$.

41. Gilbert MR, Wang M, Aldape KD, Stupp R, Hegi ME, Jaeckle KA, Armstrong TS, Wefel JS, Won M, Blumenthal DT, Mahajan A, Schultz CJ, Erridge S, et al. Dose-Dense Temozolomide for Newly Diagnosed Glioblastoma: A Randomized Phase III Clinical Trial. J Clin Oncol. 2013; 31: 4085-91.

42. Stupp R, Taillibert S, Kanner AA, Kesari S, Steinberg DM, Toms SA, Taylor LP, Lieberman F, Silvani A, Fink KL, Barnett GH, Zhu JJ, Henson JW, et al. Maintenance Therapy With Tumor-Treating Fields Plus Temozolomide vs Temozolomide Alone for Glioblastoma: A Randomized Clinical Trial. JAMA. 2015; 314: 2535-43.

43. Vredenburgh JJ, Desjardins A, Herndon JE, Marcello J, Reardon DA, Quinn JA, Rich JN, Sathornsumetee S, Gururangan S, Sampson J, Wagner M, Bailey L, Bigner DD, et al. Bevacizumab plus irinotecan in recurrent glioblastoma multiforme. J Clin Oncol. 2007; 25: 4722-9.

44. Arvold ND, Cefalu M, Wang Y, Zigler C, Schrag D, Dominici F. Comparative effectiveness of radiotherapy with vs. without temozolomide in older patients with glioblastoma. J Neurooncol. 2016; 131:301-311.

45. Surveillance, Epidemiology, and End Results (SEER) Program (www.seer.cancer.gov) Research Data (19732013), National Cancer Institute, DCCPS, Surveillance Research Program, Surveillance Systems Branch, released April 2016, based on the November 2015 submission.

46. Cancer data provided by the Texas Cancer Registry, Cancer Epidemiology and Surveillance Branch, Texas Department of State Health Services, 1100 West 49th Street, Austin, TX 78756, http://www.dshs.state.tx.us/tcr/default.shtm, or (512) 776-3080. 
47. International Classification of Diseases for Oncology, third edition, first revision. Geneva, World Health Organization, 2013.

48. Chang SM, Barker FG. Marital status, treatment, and survival in patients with glioblastoma multiforme. Cancer. 2005; 104: 1975-84.

49. Kozak KR, Mahadevan A, Moody JS. Adult gliosarcoma: epidemiology, natural history, and factors associated with outcome. Neuro Oncol. 2009; 11: 183-91.

50. Noorbakhsh A, Tang JA, Marcus LP, McCutcheon B, Gonda DD, Schallhorn CS, Talamini MA, Chang DC, Carter BS, Chen CC. Gross-total resection outcomes in an elderly population with glioblastoma: a SEER-based analysis. J Neurosurg. 2014; 120: 31-9.

51. Pan IW, Ferguson SD, Lam S. Patient and treatment factors associated with survival among adult glioblastoma patients:
A USA population-based study from 2000-2010. J Clin Neurosci. 2015; 22: 1575-81.

52. Johnson DR, Ma DJ, Buckner JC, Hammack JE. Conditional probability of long-term survival in glioblastoma. Cancer. 2012; 118: 5608-13.

53. Ghali WA, Quan H, Brant R, van Melle G, Norris CM, Faris PD, Galbraith PD, Knudtson ML, APPROACH (Alberta Provincial Project for Outcome Assessment in Coronary Heart Disease) Investigators. Comparison of 2 methods for calculating adjusted survival curves from proportional hazards models. JAMA. 2001; 286: 1494-7.

54. Zhang X, Loberiza FR, Klein JP, Zhang MJ. A SAS macro for estimation of direct adjusted survival curves based on a stratified Cox regression model. Comput Methods Programs Biomed. 2007; 88: 95-101. 